\title{
Mechanistic Studies and Design of Highly Active Cuprate Catalysts for the Direct Decomposition and Selective Reduction of Nitric Oxide and Hydrocarbons to Nitrogen for Abatement of Stack Emissions
}

\author{
Semiannual Technical Progress Report
}

Overall Project Period: October 1, 1997 - September 30, 2000

Period of this Report: $\quad$ October 1, 1997 - April 1, 1998

Principal Investigator: Ravindra Datta

Department of Chemical and Biochemical Engineering

The University of Iowa, Iowa City, IA 52241

Phone: (319) 335-1395; Fax: (319) 335-1415

E-mail: radatta@icaen.uiowa.edu

Date of Report: $\quad$ April 30, 1998

DOE Award No.: $\quad$ DE-FG26-97FT97268--01

Disclaimer: This report was prepared as an account of work sponsored by an agency of the United States Government. Neither the United States Government nor any agency thereof, nor any of their employees, makes any warranty, express or implied, or assumes any legal liability or responsibility for the accuracy, completeness, or usefulness of any information, apparatus, product, or process disclosed, or represents that its use would not infringe privately owned rights. Reference herein to any specific commercial product, process, or service by trade name, trademark, manufacturer, or otherwise does not necessarily constitute or imply its endorsement, recommendation, or favoring by the United States Government or any agency thereof. The views and opinions of authors expressed herein do not necessarily state or reflect those of the United States Government or any agency thereof.

Is any patentable subject matter disclosed in the report? Yes If so, has an invention disclosure been submitted to DOE Patent Counsel? No Are there any patent related objections to the release of this report? No 


\section{ABSTRACT}

A flow trough type catalytic reactor system was adequately modified for $\mathrm{NO}$ related catalytic and adsorption measurements, including the on-line connection of a digital chemiluminescent $\mathrm{NO}-\mathrm{NO}_{\mathrm{x}}$ analyzer to the reactor outlet system. Moreover, we have largely completed the installation of an FTIR coupled catalytic system containing a HTEC cell for high temperature DRIFT studies. Three different barium cuprate samples, $\mathrm{Ba}_{2} \mathrm{CuO}_{3}, \mathrm{BaCuO}_{2}$, and $\mathrm{Ba}_{2} \mathrm{Cu}_{3} \mathrm{O}_{5}$ were synthesized and characterized by powder XRD for catalytic tests. Prior to catalytic studies over these cuprates, a new, liquid indium based supported molten metal catalyst (In-SMMC) was tested in the reduction of $\mathrm{NO}$ by various reductants. In the presence of excess $\mathrm{O}_{2}$ and $\mathrm{H}_{2} \mathrm{O}$, the In-SMMC proved to be more active for the selective catalytic reduction (SCR) of $\mathrm{NO}$ to $\mathrm{N}_{2}$ by ethanol than most other catalysts. Using $\mathrm{C}_{1}-\mathrm{C}_{3}$ alcohols as reductants, self sustained periodic oscillations observed in the $\mathrm{NO}_{\mathrm{x}}$ concentrations of reactor effluents indicated the first time that radical intermediates can be involved in the SCR of NO by alcohols. Further, In-SMMC is the only effective and water tolerant SCR catalyst reported thus far which contains $\mathrm{SiO}_{2}$ support. Thus, this novel catalyst opens up a promising new alternative for developing an effective and durable catalyst for $\mathrm{NO}_{\mathrm{x}}$ abatement in stack emission. 
TABLE OF CONTENTS

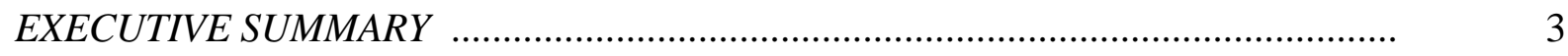

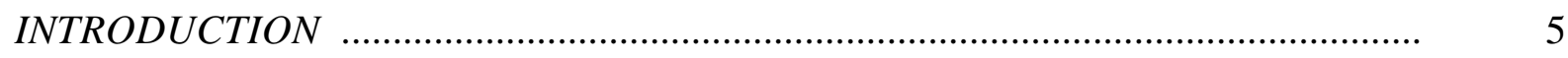

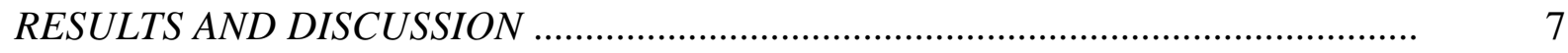

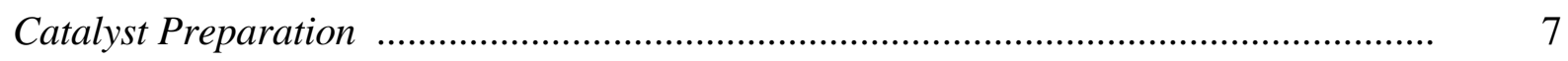

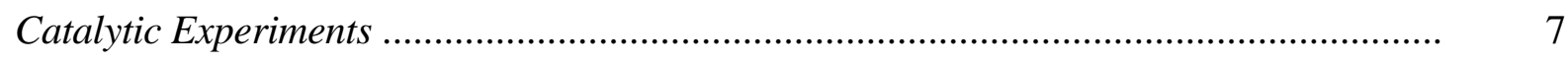

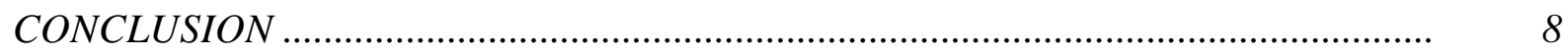

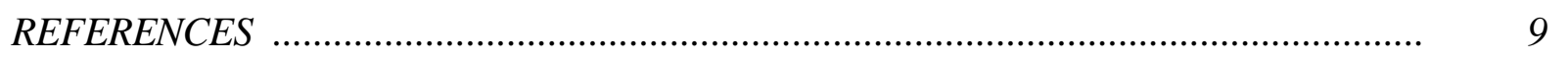

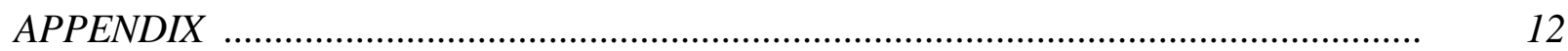




\section{EXECUTIVE SUMMARY}

The overall objective of this project is to elucidate new aspects of the mechanism of selective catalytic reduction (SCR) of nitric oxide and explore new catalytic materials in order to design better catalyst for the $\mathrm{NO}_{\mathrm{x}}$ control from coal combustion sources. The SCR of NO by hydrocarbons or oxygenated hydrocarbons has recently emerged as a promising alternative technique (HC-SCR) to overcome the limits and difficulties of the current ammonia based SCR procedure. Some ZSM5 type zeolites have been the first active HC-SCR catalysts at laboratory conditions but most of them loose catalytic activity at the harsh chemical environment of commercial exhaust and also the durability of zeolites appears to be unsatisfactory for practical use due mainly to the substantial $\mathrm{H}_{2} \mathrm{O}$ steam content of stack emissions. There is a hope that these difficulties can be overcome by avoiding the use of zeolites which generated a considerable industrial incentive to find active and durable non-zeolite based HC-SCR catalysts. The high catalytic activity of $\mathrm{Ba}_{2} \mathrm{Cu}_{3} \mathrm{O}_{5}$ holds promise to improve the current impractically low activity level of non-zeolite HC-SCR catalysts by exploring the salient activity determining features of this and other cuprate catalysts.

In accordance with the project schedule, we prepared three different barium cuprates in order to study the catalytic role of the relative ratios of copper and barium atoms. Moreover, the installation of a catalytic reactor system coupled with a Nicolet Magna-IR 560 E. S. T. FTIR spectrometer has largely been completed. In this system, the catalytic reactor is substituted by a Model 0030-103 high temperature environmental chamber (HTEC) from Spectratech which permits in situ sample pretreatment at high vacuum $\left(10^{-5}\right.$ torr $)$ and diffuse reflectance infrared analysis (DRIFT) up to $900{ }^{\circ} \mathrm{C}$. For adsorption and catalytic studies with $\mathrm{NO}_{\mathrm{x}}$ and other SCR related reactants, the reactor inlet/outlet arrangement was adequately modified in one of our existing catalytic systems including installation of supplemental heat and gas flow controllers. This modification also included the attachment, installation, and calibration of a Rosemunt type NGA 2000 chemiluminescent $\mathrm{NO}-\mathrm{NO}_{\mathrm{x}}$ analyzer which is a newly developed, digital, state of the art instrument with wide extension capabilities.

Using this $\mathrm{NO}-\mathrm{NO}_{\mathrm{x}}$ analyzer, we tested one of our newly developed supported metal catalysts (SMMC), namely liquid indium supported on porous glass (abbreviated as In-SMMC), in the reduction of $\mathrm{NO}$ by various reductants. Among many surprising results, we found this catalyst to be more active for the SCR of NO by ethanol in presence of water than any other catalyst except a comparable active $\mathrm{Ag} / \mathrm{Al}_{2} \mathrm{O}_{3}$ sample which has been published by Japanese researchers a few weeks ago. Since the outstanding catalytic activity and water resistance of the new In-SMMC is an unexpected but extremely relevant development pertaining to $\mathrm{NO}_{\mathrm{x}}$ abatement problems in stack emissions, we have postponed the scheduled catalytic studies on cuprates and focused on the new catalyst. Some pertinent publication manuscripts are attached to this report.

We intend to utilize these newly acquired results in combination with the originally planned experiments to develop better catalysts for $\mathrm{NO}_{\mathrm{x}}$ treatment in dilute flue gases from coal 
combustion. For instance, the planned In and Ga cuprates might be adequate modifications for In-SMMC for further activity and selectivity improvement. Mixing In-SMMC and $\mathrm{Ba}_{\mathrm{x}} \mathrm{Cu}_{\mathrm{y}} \mathrm{O}_{\mathrm{z}}$ seems to be also a promising new combination of non-zeolite SCR catalysts. Thus experiments in the near future will focus on testing the limits of the applications of In-SMMC, such as lowering the space velocity to the typical SV $\sim 10,000 \mathrm{~h}^{-1}$ stack emission levels and lowering the metal loading which is a financial issue on one hand and increases dispersion on the other hand. The other major short term program will be the comparison of different barium cuprates in SCR reactions. Next we intend to test the catalytic properties of adequate combinations of the two different type of catalysts in order to find a possibly practical SCR catalyst composition. Consequently, the planned adsorptive and FTIR studies going to be done as needed to help in understanding the mechanisms of these reactions and refine the composition of catalysts. 


\section{INTRODUCTION}

$\mathrm{NO}_{\mathrm{x}}$ emitted from various coal-fueled combustion sources is an unwanted major air pollutant which can aggravate chronic hearth and respiratory diseases, contributes to the acid rainfall, ground level ozone, and depletion of the stratospheric ozone layer [1]. Therefore, a great deal of effort is being made to reduce $\mathrm{NO}_{\mathrm{x}}$ emissions. Catalytic techniques appear to be most effective means of combating $\mathrm{NO}_{\mathrm{x}}$ pollution to satisfy the increasingly stricter environmental requirements.

There are a number of different technical approaches that may be considered for the catalytic reduction of $\mathrm{NO}_{\mathrm{x}}$ emission from stationary combustion sources but all current technologies have limitations pertaining to $\mathrm{NO}_{\mathrm{x}}$ abatement from coal combustion. For example, the catalytic combustion is only efficient for preventing the high temperature formation of flame generated $\mathrm{NO}_{\mathrm{x}}$ from air but not from chemically bound nitrogen in coal, coal derived fuels, or residual oils [2]. The extremely complex conditions of staged burning, in which the fuel-bond nitrogen is converted to $\mathrm{N}_{2}$ in a primary combustion zone at fuel-rich conditions and the produced $\mathrm{CO}$ and hydrocarbons are burned in a second fuel-lean (excess oxygen) zone, can cause unstable combustion and hence unstable control of $\mathrm{NO}_{\mathrm{x}}$ emission [2].

Currently the catalytic reduction of $\mathrm{NO}_{\mathrm{x}}$ in the post-combustion zone appears to be the most promising technique to attain the required low $\mathrm{NO}_{\mathrm{x}}$ levels in stack emissions. Since the typical exhausts from coal burning are rich in oxygen, this post-combustion technique requires the injection of selective reductants which preferably react with $\mathrm{NO}$ instead of the excess $\mathrm{O}_{2}$. The selective catalytic reduction (SCR) of $\mathrm{NO}$ by $\mathrm{NH}_{3}$ is a rapidly spreading commercial technology for efficient $\mathrm{NO}_{\mathrm{x}}$ removal from oxygen rich exhausts. However, this technique has numerous problems including storage, handling, and escape of unreacted ammonia [1,2].

Since 1990, a number of selective reductants, including various hydrocarbons and alcohols, have been found to be potential alternatives of ammonia for the reduction of NO under oxidizing conditions [1,3]. Some ZSM5 type zeolites are so far the most active and selective catalysts for the SCR of NO by hydrocarbons or oxygenated hydrocarbons. However, the catalytic activity of most zeolites substantially decreases in presence of $\mathrm{H}_{2} \mathrm{O}$, which is inevitably present in the exhaust streams. Moreover, the hydrothermal stability of zeolites is a concern. Therefore, developing an effective and durable non-zeolite type SCR catalyst is an important task. Since the reaction rate of various SCR related reactions was found to be much faster over a $\mathrm{Ba}_{2} \mathrm{Cu}_{3} \mathrm{O}_{5}$ catalyst sample than those over the most studied $\mathrm{Cu}-\mathrm{ZSM} 5$, there is a hope that a better SCR catalyst can be developed for treating the dilute fuel gas streams from coal combustion by exploring those fundamental surface and bulk properties of cuprates which have pronounced effect on their SCR related catalytic activities and selectivities. This task is the major objective of the proposed research.

As a result of the intensive worldwide research since the preparation of our research proposal, some $\mathrm{In}_{2} \mathrm{O}_{3}$ based complex solids have emerged as very promising, highly active, steam 
and $\mathrm{SO}_{2}$ resistant SCR catalysts [4-10]. Therefore we tested one of our newly developed supported molten metal catalysts (SMMC) [14-16] which contains liquid indium (In-SMMC) in $\mathrm{SCR}$ related reactions. In the presence of $\mathrm{H}_{2} \mathrm{O}$, In-SMMC was found to be more active for the SCR of NO by alcohol than any other indium containing sample (and most zeolite or non-zeolite SCR catalysts). Thus, these new, unexpected results form the body of the present report.

\section{RESULTS AND DISCUSSION}

\section{$\underline{\text { Catalyst Preparation }}$}

Three different barium cuprate phases, $\mathrm{Ba}_{2} \mathrm{CuO}_{3}, \mathrm{BaCuO}_{2}$, and $\mathrm{Ba}_{2} \mathrm{Cu}_{3} \mathrm{O}_{5}$ were fabricated by solid state reactions of $\mathrm{CuO}\left(99+\%\right.$ purity) or $\mathrm{Cu}\left(\mathrm{NO}_{3}\right)_{2} \times 2.5 \mathrm{H}_{2} \mathrm{O}$ (98\% purity) and $\mathrm{Ba}\left(\mathrm{NO}_{3}\right)_{2}(99+\%$ purity) from Aldrich with slight modifications compared to the original recipes [11-13]. In all procedures, appropriate stoichiometric amounts of the starting nitrates or oxides were thoroughly mixed and ground. The mixtures were calcined in porcelain or nickel (for $\mathrm{BaCuO}$ ) crucibles in air for 24 hours at $920{ }^{\circ} \mathrm{C}, 940{ }^{\circ} \mathrm{C}$, and $750{ }^{\circ} \mathrm{C}$ for $\mathrm{Ba}_{2} \mathrm{CuO}_{3}, \mathrm{BaCuO}_{2}$, and $\mathrm{Ba}_{2} \mathrm{Cu}_{3} \mathrm{O}_{5}$, respectively.

The phase purity of these crystalline materials was examined by powder XRD using a Siemens type D5000 diffractometer equipped with an energy sensitive detector $\left(\mathrm{Cu}-\mathrm{K}_{\mathrm{a} 1,2}\right.$ source). The diffractograms are enclosed. Peaks were matched with those in the corresponding computerized JCPDF file. In the case of $\mathrm{BaCuO}$, the starting nitrates reacted with the $\mathrm{Ni}$ crucible thus this cuprate contains substantial $\mathrm{NiO}$ (Bunsenite) impurity judged by the characteristic reflections at around $2 \mathrm{Q}=37.2,43.2$, and 62.5. The synthesis of $\mathrm{BaCuO}_{2}$ will be repeated in ceramic crucible.

Two different techniques were used to fabricate In-SMMC samples: i) Direct imbibition of molten indium onto the support. For this preparation, the support was calcined first in air at around $150{ }^{\circ} \mathrm{C}$ to remove adsorbed $\mathrm{H}_{2} \mathrm{O}$ than mixed intensively with appropriate amounts of the liquid metals near $200{ }^{\circ} \mathrm{C}$ until all visible metal droplets disappeared. ii) Chemical deposition starting by adsorption of $\mathrm{In}\left(\mathrm{NO}_{3}\right)_{3}$ from aqueous solutions onto the catalyst carrier (incipient wetness) followed by drying at $120{ }^{\circ} \mathrm{C}$ for 5 hours, calcining at $550{ }^{\circ} \mathrm{C}$ for 24 hours, and reducing in a flow of $\mathrm{H}_{2}\left(100 \mathrm{~cm}^{3} / \mathrm{min}\right)$ at $550{ }^{\circ} \mathrm{C}$ for 2 hours. Some details regarding the porosity, dispersion, surface area, etc., of these samples have been described in our earlier papers [14, 15].

\section{Catalytic Experiments}

Prior to experiments with NO, we performed exploratory studies on a new class of heterogeneous catalysts, called supported molten-metal catalysts or SMMCs. As opposed to existing supported metal catalysts, composed of solid metal crystallines, finely dispersed on the extensive surface of porous refractory supports, SMMCs contain micro-droplets or ultra-thin 
films of non-transition metals melting below the temperature of the catalytic process. A large number of relatively low melting $\left(<500{ }^{\circ} \mathrm{C}\right)$, inexpensive, and abundant metals, semimetals, alloys, or intermetallic compounds are potential ingredients for SMMCs which are inherently resistant to sintering or coking and posses largely homogeneous surface sites for selective catalysis. Many of these new materials have been found to be active and selective catalysts for different reactions including the dehydrogenation of hydrocarbons $[15,16]$ and partial oxidation of alcohols [14].

Among various potential SMMC supports, a controlled pore glass $(\sim 75 \AA$ average pore radius, sold by Aldrich) proved to be appropriate to maintain dispersed, for example, molten indium. This support is obviously resistant to steaming even at high temperatures which is a problem with many potential catalysts considered for abating $\mathrm{NO}_{\mathrm{x}}$ in the oxygen and water rich exhausts of coal combustion. Therefore, when our catalytic system was modified for $\mathrm{NO}_{\mathrm{x}}$ related studies and completed with a chemiluminescent $\mathrm{NO}-\mathrm{NO}_{\mathrm{x}}$ analyzer, we tested a porous glass supported In catalyst, In-SMMC, as potential water resistant catalyst for the HC-SCR of NO by $\mathrm{C}_{3} \mathrm{H}_{8}$. Since $\mathrm{SMM}$ catalysts have not been examined in reactions of $\mathrm{NO}$ before, we also tested the effect of other typical NO reductants, such as $\mathrm{H}_{2}, \mathrm{CO}$, and $\mathrm{C}_{1}-\mathrm{C}_{3}$ alcohols.

While In-SMMC was largely inactive for the SCR of NO by the hydrocarbon (and also by $\mathrm{H}_{2}$ or $\mathrm{CO}$ ) in presence of excess oxygen, this new material showed surprisingly high catalytic activity for the same reaction when alcohol (oxygenated hydrocarbon) was used as reductant being thus the first $\mathrm{SiO}_{2}$ supported catalyst which shows appreciable activity for this process. What is more, In-SMMC is one of the most active catalysts for the HC-SCR of NO by Et-OH in the presence of $\mathrm{H}_{2} \mathrm{O}$ explored thus far. The experimental details and some major result are described in the attached presentation abstract and paper manuscript.

During our experiments, self sustained periodic oscillations were observed at various reaction conditions. Similar oscillation effects provided direct experimental proof for the involvement of radicals in the HC-SCR of NO by hydrocarbons [17-19], but oscillations in the presence of alcohols have not been reported before. This matter is the subject of another manuscript in preparation. We only attach here one example for the observed oscillations in the HC-SCR of NO by Met-OH and further details will be submitted in our next report.

\section{CONCLUSIONS}

1. In-SMMC is more active for the SCR of $\mathrm{NO}$ by Et-OH in presence of excess $\mathrm{O}_{2}$ and $\mathrm{H}_{2} \mathrm{O}$ than any other In-based catalysts. Among all catalysts reported for this reaction, only a very recently discovered $\mathrm{Ag} / \mathrm{Al}_{2} \mathrm{O}_{3}$ sample has comparable SCR activity and selectivity as the In-SMMC.

2. The porous glass supported In-SMMC is the first effective SCR catalyst which contains $\mathrm{SiO}_{2}$ type support. $\mathrm{H}_{2} \mathrm{O}$ improves both the activity and the selectivity of this catalyst. 
3. Results indicate that oxidation of Et-OH is a likely initial reaction in the SCR process over the In-SMMC and $\mathrm{NO}_{2}$ forms in secondary reactions.

4. Periodic oscillations in the $\mathrm{NO}$ and $\mathrm{NO}_{2}$ concentrations of the products were observed the first time in alcohol induced SCR reactions. Thus, homogeneous and heterogeneous radical reactions are likely involved in the SCR of NO over In-SMMC.

\section{REFERENCES}

[1] J. N. Armor, Appl. Catal. B: Environmental 1(1992) 221.

[2] Z. R. Ismagilov, M. A. Kerzhentsev, Catal. Rev. Sci. Eng. 32 (1990) 51.

[3] M. Shelef, Chem. Rev. 95 (1995) 209.

[4] X. Zhou, T. Zhang, Z. Xu, L. Lin, Catal. Lett. 40 (1996) 35.

[5] T. Tabata, M. Kokitsu, O. Okada, Appl. Catal. B: Environmental, 6 (1995) 225.

[6] E. Kikuchi, M. Ogura, I. Terasaki, Y. Goto, J. Catal. 161 (1996) 465.

[7] T. Miyadera, K. Yoshida, Chem. Lett. 1483 (1993).

[8] T. Maunula, Y. Kintaichi, M. Inaba, M. Haneda, K. Sato, H. Hamada, Appl. Catal. B: Environmental 15 (1998) 291.

[9] Y. Kintaichi, M. Haneda, M. Inaba, H. Hamada, Catal. Lett. 48 (1997) 121.

[10] M. Haneda, Y. Kintaichi, M. Inaba, H. Hamada, Bull. Chem. Soc. Jpn. 70 (1997) 2171.

[11] M. Arjomand, D. J. Machin, J. Chem. Soc. Dalton 1061 (1975).

[12] D. M. DeLeeuw, C. A. H. A. Mutsaers, C. Langereis, H, C. A. Smoorenburg, P. J. Rommers, Physica C152 (1988) 39.

[13] I. Halasz, V. Fulop, I. Kirschner, T. Porjesz, J. Crystal Growth 91 (1988) 944, and 92 (1988) 692.

[14] I. Halasz, R. Datta, Appl. Catal. A: General, in preparation.

[15] I. Halasz, A. Singh, M. Serban, R. Datta, Science, in preparation.

[16] R. Datta, I. Halasz, M. Serban, A. Singh, US Patent, pending.

[17] A. Obuchi, M. Nakamura, A. Ogata, K. Mizuno, A. Ohi, H. Obuchi, J. Chem. Soc. Chem. Commun. 1150 (1992).

[18] I. Halasz, A. Brenner, M. Shelef, K. Y. S. Ng, J. Phys. Chem. 99 (1995) 17186.

[19] B. K. Cho, J. E. Yie, K. M. Rahmoeller, J. Catal. 157 (1995) 14. 


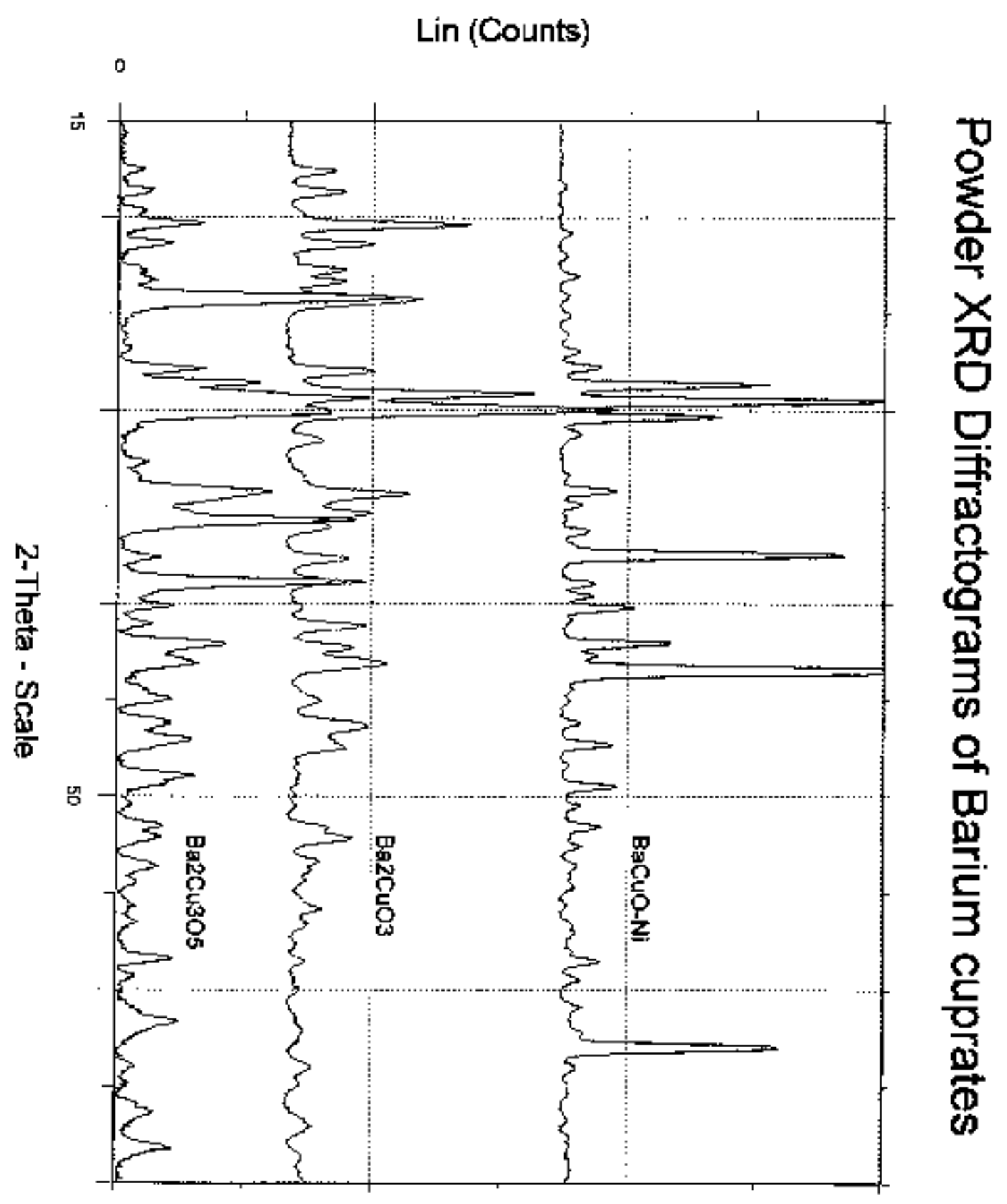




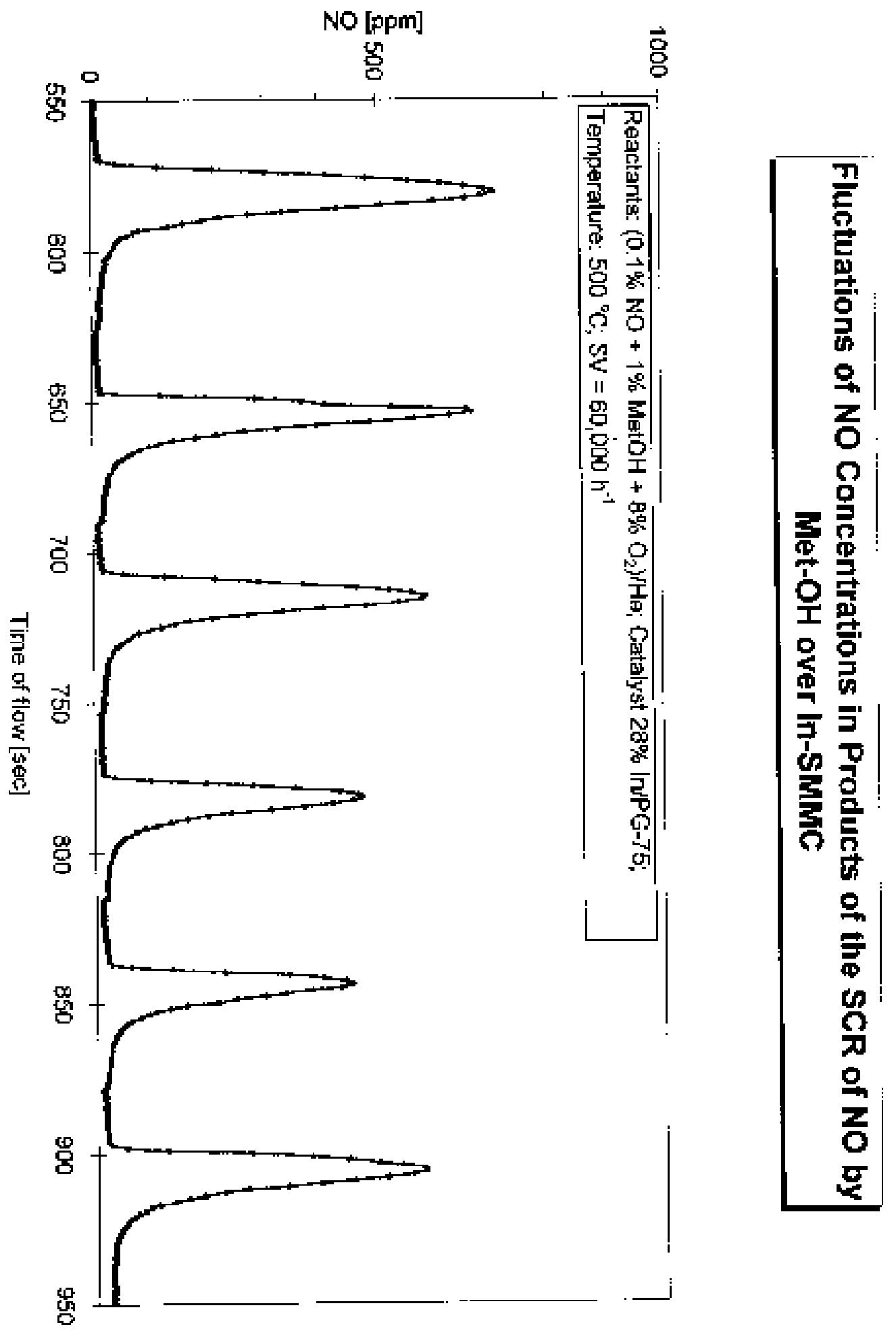


APPENDIX 


\title{
NEW WATER TOLERANT SUPPORTED MOLTEN METAL CATALYSTS (SMMC) FOR THE SELECTIVE REDUCTION OF NITRIC OXIDE BY ALCOHOLS
}

\author{
Istvan Halasz, Cory Phillips, and Ravindra Datta \\ Department of Chemical and Biochemical Engineering \\ The University of Iowa, Iowa City, IA 52242
}

In contrast to common supported metal catalysts composed of solid metal crystallines dispersed on porous supports, supported molten metal catalysts or SMMCs, a new class of catalysts, contain micro droplets or thin films of non-transition low melting metals on refractory supports. The SMMCs have been found to catalyze various dehydrogenation and selective oxidation processes [1]. However, the full potential of this large group of heterogeneous catalysts has yet to be explored.

Here we report the first observation of very high catalytic activity and good water tolerance of some SMMC samples in the selective catalytic reduction (SCR) of NO by alcohols at reaction conditions resembling those in the commercial catalytic converters for $\mathrm{NO}_{\mathrm{x}}$ abatement in combustion exhausts. The SCR of NO by hydrocarbons or oxygenated hydrocarbons is a promising technique for minimizing $\mathrm{NO}_{\mathrm{x}}$ emissions from oxygen rich exhausts of stationary or mobile sources [2, 3]. Some ZSM5 type zeolites are so far the most active SCR catalysts (Table 1). However, the catalytic activity of most zeolites substantially decreases in presence of $\mathrm{H}_{2} \mathrm{O}$, which is always present in exhaust streams. Moreover, the low hydrothermal stability of zeolites is a concern.

Catalytic experiments were carried out with mixtures of $\left(0.1 \% \mathrm{NO}+8 \% \mathrm{O}_{2}+\mathrm{x} \% \mathrm{C}_{1}-\mathrm{C}_{3}\right.$ alcohol $+\mathrm{y} \% \mathrm{H}_{2} \mathrm{O}$ ) in $\mathrm{He}$ carrier gas at temperatures from 300 to $600{ }^{\circ} \mathrm{C}$ and space velocities $\mathrm{SV}$ $\geq 10,000 \mathrm{~h}^{-1}$ over various SMMC samples. The concentration of alcohol was varied from zero to $2 \%$ and that of water from 3 to $10 \%$. The effect of metal loading and nature of support on the activity and selectivity of catalysts was also studied. To get comparative information about the catalytic performance of SMMCs for the reduction of NO by various reductants, experiments were also done by using $\mathrm{H}_{2}, \mathrm{CO}$, and hydrocarbons instead of alcohols. The reaction steps were probed by using bimolecular feeds of $\left(\mathrm{NO}+\mathrm{O}_{2}\right),(\mathrm{NO}+$ alcohol $)$ and $\left(\mathrm{O}_{2}+\right.$ alcohol $)$. Adsorption isotherms and thermogravimetric measurements were used to characterize the surface sites of catalysts.

As the example of In-SMMC indicates in Table 1, this catalyst is more active for the SCR of $\mathrm{NO}$ by Et-OH in presence of excess $\mathrm{O}_{2}$ and $\mathrm{H}_{2} \mathrm{O}$ than any other catalysts reported for this reaction. Catalyst performance remained largely intact when catalytic tests were carried out at various reaction conditions for an extended period. Periodic oscillations were also observed in the $\mathrm{NO}$ and $\mathrm{NO}_{2}$ concentrations of the products. Water affects both the amplitude and the frequency of these oscillations.

\footnotetext{
* ABSTRACT SUBMITTED TO SECOND WORLD CONGRESS ON ENVIRONMENTAL CATALYSIS, MIAMI, FL, NOV. 15, 1998.
} 
Table 1. Catalytic Activities of Various Catalysts for the SCR of NO by Et-OH ; Reactants: (0.05-0.1)\% NO + (0.2-1\%) Et-OH + (8-10)\% $\mathrm{O}_{2}+(3-10) \% \mathrm{H}_{2} \mathrm{O}$

\begin{tabular}{|c|c|c|c|c|c|}
\hline \multirow[t]{2}{*}{ Catalyst } & \multicolumn{3}{|c|}{ NO Conversion to $\mathrm{N}_{2}[\%]$} & \multirow[t]{2}{*}{$\mathbf{S V}\left[\mathbf{h}^{-1}\right]$} & \multirow[t]{2}{*}{ Reference } \\
\hline & $300{ }^{\circ} \mathrm{C}$ & $400{ }^{\circ} \mathrm{C}$ & $500{ }^{\circ} \mathrm{C}$ & & \\
\hline In-SMMC & 22 & 38 & 41 & 60,000 & Present work \\
\hline $\mathrm{Pd}-\mathrm{In}_{2} \mathrm{O}_{3} / \mathrm{TiO}_{2}-\mathrm{ZrO}_{2}$ & 15 & 22 & 10 & 40,000 & {$[4]$} \\
\hline$\gamma-\mathrm{Al}_{2} \mathrm{O}_{3}$ & 2 & 10 & 19 & 20,000 & {$[5]$} \\
\hline $\mathrm{Ag} / \mathrm{Al}_{2} \mathrm{O}_{3}$ & 42 & 41 & -- & 6,400 & {$[6]$} \\
\hline $\mathrm{CoO}_{\mathrm{x}} / \mathrm{Al}_{2} \mathrm{O}_{3}$ & 48 & 28 & 24 & 2,000 & {$[7]$} \\
\hline H-ZSM5 & 18 & 19 & 10 & 20,000 & {$[7]$} \\
\hline Cu-ZSM5 & 28 & 15 & 10 & 20,000 & {$[7]$} \\
\hline $\mathrm{Cu}-\mathrm{ZSM} 5$ & -- & -- & 25 & 50,000 & {$[8]$} \\
\hline
\end{tabular}

Results also indicate that oxidation of Et-OH is a likely initial reaction in the SCR process over the In-SMMC. As opposed to most other SCR catalysts $[2,9,10]$, formation of $\mathrm{NO}_{2}$ has presumably a secondary role over this catalyst. Similar to the SCR of NO by $\mathrm{C}_{3} \mathrm{H}_{6}$ over $\mathrm{Mn}_{2} \mathrm{O}_{3} / \mathrm{Sn}-\mathrm{ZSM} 5$ [11], $\mathrm{H}_{2} \mathrm{O}$ improves both the activity and the selectivity of In-SMMC. Homogeneous and heterogeneous radical reactions may be involved in the SCR of NO over SMMC samples studied.

\section{References}

[1] I. Halasz, A. Singh, M. Serban, R. Datta, in preparation.

[2] M. Shelef, Chem. Rev. 95, 209 (1995).

[3] J. N. Armor, Appl. Catal. B: Environmental 1, 221 (1992).

[4] M. Haneda, Y. Kintaichi, M. Inaba, H. Hamada, Bull. Chem. Soc. Jpn. 70, 2171 (1997).

[5] H. Hamada, Y. Kintaichi, T. Yoshinari, M. Tabata, M. Sasaki, T. Ito, Catal. Today 17, 111 (1993).

[6] T. Miyadera, Appl. Catal. B: Environmental 2, 199 (1993).

[7] H. Hamada, Y. Kintaichi, M. Sasaki, T. Ito, Appl. Catal. A: General 88, L1 (1992).

[8] C. N. Montreuil, M. Shelef, Appl. Catal. B: Environmental 1, L1 (1992).

[9] Y. Kintaichi, M. Haneda, M. Inaba, H. Hamada, Catal. Lett. 48, 121 (1997).

[10] I. Halasz, A. Brenner, Catal. Lett., in press.

[11] Y. Hiraho, C. Yokoyama, M. Misono, Chem. Commun. 597 (1996). 


\title{
EFFICIENT REDUCTION OF NITRIC OXIDE BY ALCOHOLS IN PRESENCE OF EXCESS OXYGEN AND WATER OVER A NEW INDIUM BASED SUPPORTED MOLTEN METAL CATALYST (SMMC) ${ }^{*}$
}

\author{
Istvan Halasz and Ravindra Datta \\ The University of Iowa, Dept. Chem. \& Biochem. Eng., Iowa City, IA 52242
}

The catalytic activity and selectivity of liquid In supported on controlled pore glass $(\sim 75 \AA$ radius) was investigated in the reduction of $\mathrm{NO}$ by $\mathrm{H}_{2}, \mathrm{CO}, \mathrm{C}_{3} \mathrm{H}_{8}$, and $\mathrm{C}_{1}-\mathrm{C}_{3}$ alcohols at net oxidizing and reducing conditions in the presence and absence of water at reaction temperatures from 300 to $550{ }^{\circ} \mathrm{C}$ and $\mathrm{SV}=60,000 \mathrm{~h}^{-1}$. Unlike other $\mathrm{SiO}_{2}$ supported catalysts, the In-SMMC proved to be highly active for the SCR of NO by alcohols but not with the other reductants. This catalyst can reduce $\mathrm{NO}$ to $\mathrm{N}_{2}$ by Et-OH in presence of $\mathrm{H}_{2} \mathrm{O}$ with comparable efficiency as the most effective catalysts reported for this reaction thus far. It appears that the partial oxidation of alcohol initiates the SCR process and $\mathrm{NO}_{2}$ forms in secondary reactions over InSMMC. Radicals are likely involved in this process.

\footnotetext{
* MANUSCRIPT IN PREPARATION TO PUBLISH IN APPLIED CATALYSIS B: ENVIRONMENTAL
} 


\section{INTRODUCTION}

The selective catalytic reduction (SCR) of NO by hydrocarbons or oxygenated hydrocarbons is a promising technique to minimize $\mathrm{NO}_{\mathrm{x}}$ emissions from oxygen rich exhausts of stationary or mobile combustion sources [1,2]. Since the first public insertions of the high SCR activity of copper [3, 4] and proton [5] exchanged ZSM5 zeolites, a large throng of zeolites has been examined as catalyst candidates for this reaction. However, water vapor which inevitably appears in exhausts of all combustion sources, typically inhibits the SCR activity of most zeolites and their hydrothermal stability seems to be also too low for commercial use [6-9]. Maintaining high $\mathrm{Si} / \mathrm{Al}$ ratios in zeolites can help to prevent further dealumination or lattice destruction but only at temperatures $<650{ }^{\circ} \mathrm{C}[10-12]$. Very recent papers indicate that even the activity inhibiting effect of $\mathrm{H}_{2} \mathrm{O}$ can be prevented in the SCR of $\mathrm{NO}$ by iso- $\mathrm{C}_{4} \mathrm{H}_{10}$ when the highly active Fe-ZSM5 is used as catalyst and its Brönsted acidic sites are fully exchanged by $[\mathrm{FeOH}]^{+}[9]$ or $\left[\mathrm{FeCl}_{2}\right]^{+}[13]$ ions. Nevertheless, there is considerable industrial incentive for finding active non-zeolite based SCR catalysts which in general are more resistant to high temperature steaming than zeolites.

The good water $\left(\right.$ and $\mathrm{SO}_{2}$ ) tolerance of various indium based SCR catalysts has attracted considerable research attention recently. In, H-ZSM5 has been reported to be a more active catalysts for the SCR of $\mathrm{NO}$ by $\mathrm{CH}_{4}$ in presence of $\mathrm{H}_{2} \mathrm{O}$ than most other catalysts [8, 14-17]. It is conjectured, that the acidic zeolite also serves as a support for finely dispersed, catalytically active $\operatorname{In}_{2} \mathrm{O}_{3}$ particles in these catalysts (bifunctional catalysis) [15, 17]. When $\operatorname{In}_{2} \mathrm{O}_{3}$ is deposited on less acidic supports, such as $\mathrm{Al}_{2} \mathrm{O}_{3}[15,18,19]$ or $\mathrm{TiO}_{2}-\mathrm{ZrO}_{2}[20,21]$, its catalytic 
activity for the SCR of $\mathrm{NO}$ by $\mathrm{CH}_{4}$ largely diminishes. However, these catalysts showed appreciable catalytic activities for the SCR of $\mathrm{NO}$ by $\mathrm{C}_{2}-\mathrm{C}_{3}$ hydrocarbons and alcohols both in the absence and the presence of $\mathrm{H}_{2} \mathrm{O}$ [15, 18-21]. It has been very recently demonstrated [19] that a specially prepared "sol-gel" $\gamma-\mathrm{Al}_{2} \mathrm{O}_{3}$ support outperforms all other materials, including existing commercial $\gamma-\mathrm{Al}_{2} \mathrm{O}_{3}$ supports. In contrast, these authors found that $\operatorname{In}_{2} \mathrm{O}_{3}$ dispersed on $\mathrm{SiO}_{2}$ is less active than the unsupported $\mathrm{In}_{2} \mathrm{O}_{3}$ [19]. Another $\mathrm{SiO}_{2}$ support has been reported to destroy the catalytic activity of $\mathrm{SnO}_{2}$ for the SCR of $\mathrm{NO}$ by Met-OH [22]. The poor performance of $\mathrm{SiO}_{2}$ supports for numerous transition metal based SCR catalysts has also been demonstrated [53]. Since the acidic $\mathrm{Al}_{2} \mathrm{O}_{3}, \mathrm{TiO}_{2}, \mathrm{Al}_{2} \mathrm{O}_{3}-\mathrm{SiO}_{2}$, etc., are active SCR catalysts themselves [22-25] but $\mathrm{SiO}_{2}$ not [19, 22, 53], many researchers agree that only the former oxides can provide a strong catalyst-support interaction necessary for the SCR process [19-24].

In the course of our endeavor for exploring some properties of a new group of heterogeneous catalysts, called supported molten metal catalysts or SMMCs [26-30], we observed outstanding $\mathrm{N}_{2}$ production in the SCR of NO by some alcohols over liquid In supported on porous glass. Although this support is almost pure (>96\%) $\mathrm{SiO}_{2}$, the In-SMMC was found to be more active for this reaction in presence of $\mathrm{H}_{2} \mathrm{O}$ than other In- based catalysts including their variously promoted derivatives [19-21]. This paper describes some details of our experimental findings. Since SMMC samples have not been studied in NO-related reactions, the effects of $\mathrm{H}_{2}, \mathrm{CO}, \mathrm{C}_{3} \mathrm{H}_{8}$, and $\mathrm{O}_{2}$ on $\mathrm{NO}$ over In-SMMC have also been investigated. To approximate the typical conditions in catalytic converters for vehicular [2, 31] and stack [32-34] emissions, all experiments were carried out at space velocities SV $>10,000 \mathrm{~h}^{-1}$ and all SCR experiments were done at $\mathrm{SV}=60,000 \mathrm{~h}^{-1}$. 


\section{EXPERIMENTAL}

\section{Catalysts and Materials}

Controlled pore glass from Aldrich (80-120 mesh, mean pore radius $75 \pm 5 \AA$, pore volume $\mathrm{V} \sim 0.47 \mathrm{~cm}^{3} / \mathrm{g}$, specific surface area SA $\sim 140 \mathrm{~m}^{2} / \mathrm{g}$ ) was used as catalyst support and denoted as PG-75 throughout this paper. High purity In (99.99\%) from Aldrich was used to deposit 27.7 w. \% metal (calculated amount for monoatomic surface coverage) by direct imbibition. The specific gravity, specific surface area, pore volume, and average pore diameter of PG-75 pretreated at the same conditions as the catalyst (see below) were $0.5662 \mathrm{~g} / \mathrm{cm}^{3}, 171 \mathrm{~m}^{2} / \mathrm{g}$, $0.565 \mathrm{~cm}^{3} / \mathrm{g}$ and $64 \AA$ and the same values for the $28 \% \mathrm{In} / \mathrm{PG}-75$ catalyst were $0.8224 \mathrm{~g} / \mathrm{cm}^{3}, 138$ $\mathrm{m}^{2} / \mathrm{g}, 0.471 \mathrm{~cm}^{3} / \mathrm{g}$ and $71 \AA$, respectively. Details of the preparation as well as the porosity and surface measurements are described elsewhere [27, 28].

Anhydrous methanol (99.8\%) form EM Science, ethanol (99.5\%) from Pharmaco Products, and 2-propanol (99.5\%) from Aldrich were used for catalytic measurements. For studying the effect of water, these alcohols were mixed with the necessary amounts of deionized $\mathrm{H}_{2} \mathrm{O}$.

The reactant gases for catalytic measurements were Helium diluted certified mastergases from Scott in various concentrations. Pure $\mathrm{H}_{2}(99.99 \%), \mathrm{He}(99.995 \%)$, and $\mathrm{N}_{2}(99.95 \%)$ from Air Products were further purified using Mattheson $\mathrm{O}_{2}$ and $\mathrm{H}_{2} \mathrm{O}$ traps. All other gases were used as received. 


\section{Activity measurements and analysis}

To attain different space velocities from SV $=12,000$ to $\mathrm{SV}=120,000 \mathrm{~h}^{-1}$ while maintaining a total gas flow rate of $100 \mathrm{~cm}^{3} / \mathrm{min}$ (also includes vapors from injected liquids such as $\mathrm{H}_{2} \mathrm{O}$ and alcohols), appropriate amounts of catalyst was placed in a fused quartz reactor of the flow-through type. The catalyst was either supported on a porous quartz frit and covered with quartz wool or placed between quartz wool plugs. Prior to the first catalytic measurement, the catalyst was evacuated at $10^{-6}$ torr at $550{ }^{\circ} \mathrm{C}$ and reduced in $100 \mathrm{~cm}^{3} / \mathrm{min}_{2}$ at $0.1 \mathrm{MPa}$ for 120 minutes at this temperature. Finally the catalyst was cooled in He flow $\left(100 \mathrm{~cm}^{3} / \mathrm{min}\right)$ to the temperature of measurements and kept under He between runs.

Using a stainless steel manifold system constructed of Swagelok bellows seal valves and adapters and connected directly to our catalytic reactor/analyzer system, appropriate amounts of oxygen, nitric oxide, hydrogen, carbon monoxide, propane, methanol, ethanol, and 2-propanol were mixed with balancing helium to achieve a total flow rate of $100 \mathrm{~mL} / \mathrm{min}$. at 1 atm $\left(1.0 \times 10^{5} \mathrm{~Pa}\right)$. Flow rates were controlled by MKS type 1179 mass flow controllers. For experiments with alcohols and water, a Gilson Model 302 liquid pump injected the liquid into the gas stream via a preheater zone and the gas flow rates were adequately adjusted to maintain a total of $100 \mathrm{~mL} / \mathrm{min}$. gas flow rate at the reactor inlet. Experiments were carried out at reaction temperatures from 200 to $550{ }^{\circ} \mathrm{C}$. Details of the system are described elsewhere $[27,28]$.

Separate measurements of the nitric oxide and total $\mathrm{NO}_{\mathrm{x}}$ contents in the reactor effluent were made using a Rosemount Model NGA 2000 chemiluminescent NO-NO $\mathrm{x}_{\mathrm{x}}$ gas analyzer and were compared with the nitric oxide contents at the reactor inlet to calculate the conversion of 
nitric oxide. Since $\mathrm{N}_{2}$ and $\mathrm{N}_{2} \mathrm{O}$ were not analyzed separately the extent of $\mathrm{NO}$ reduction to $\left(\mathrm{N}_{2}+\right.$ $\mathrm{N}_{2} \mathrm{O}$ ) was calculated from the difference of inlet and outlet $\left(\mathrm{NO}+\mathrm{NO}_{\mathrm{x}}\right)$. The analyzer was calibrated with different concentrations of known gases. Recalibration was necessary in the presence of various reductants. Separate calibrations were made in $\mathrm{NO}$ and $\mathrm{NO}_{\mathrm{x}}$ mode. Blank runs were carried out at identical conditions to the experiments to determine the conversion of NO and $\mathrm{NO}_{\mathrm{x}}$ in the background which were subtracted from the results of catalytic experiments. The effluent was passed trough a condenser to remove water and alcohol from gases entering the NO$\mathrm{NO}_{\mathrm{x}}$ analyzer. Nitrogen oxide trapping in the condenser was negligible because the total $\mathrm{NO}_{\mathrm{x}}$ remained the same (within $\pm 0.5 \mathrm{ppm}$ range) when gases from the reactor outlet were either passed trough the condenser or trough a bypass system. To satisfy the minimum flow requirements in the $\mathrm{NO}-\mathrm{NO}_{\mathrm{x}}$ analyzer, the reactor effluent was mixed with $900 \mathrm{~mL} / \mathrm{min}$. flow of $\mathrm{He}$ (a tenfold dilution) before entering the analyzer. Analysis was performed at various time intervals from 1 sec to 2 min. and the average of numerous (frequently several thousand) measurements was used to characterize the conversion of NO at a given reaction condition. Repeated measurements on the same catalyst (after miscellaneous intervening reactions) and on separate weight-ins gave a total repeatability of $\pm 5 \%$. With respect to the low probability of $\mathrm{NH}_{3}$ formation at the strongly oxidizing conditions of the SCR process, the ammonia content in the effluent was not analyzed.

The $\mathrm{NO}$ and $\mathrm{NO}_{\mathrm{x}}$ concentrations were monitored continuously by passing the total effluent gas stream through the $\mathrm{NO}-\mathrm{NO}_{\mathrm{x}}$ analyzer. All other products were analyzed in separate experiments by gas chromatography using a SRI 8610C type gas chromatograph equipped with both FID and TCD detectors. The GC is connected on-line to the outlet of the catalytic system. To avoid the condensation of liquids, the sample loop and the gas lines were 
heated to about $140^{\circ} \mathrm{C}$. A $40 \times 1 / 8^{\prime \prime}$, Poropack T (80/100 mesh) filled, stainless steel column was used at $80{ }^{\circ} \mathrm{C}$ to separate and identify products from reactions of Et-OH and $\mathrm{C}_{3} \mathrm{H}_{8}$ and a 20 x 1/8", Hayesep D (100/120 mesh) filled, nickel column was used with temperature programming from 75 to $120{ }^{\circ} \mathrm{C}$ to separate and identify products from reactions of Met-OH. Products from the reaction of 2-propanol were not measured at this time. To avoid the condensation of liquids, the sample loop and the gas lines between the reactor and the GC were heated to about $140{ }^{\circ} \mathrm{C}$. Compounds monitored on $\mathrm{GC}$ were $\mathrm{CO}, \mathrm{CO}_{2}, \mathrm{C}_{1}-\mathrm{C}_{6}$ hydrocarbons, $\mathrm{H}_{2} \mathrm{O}$, alcohols, ethers, acids, aldehydes, and esters [28]. The accuracy of repeated GC analyses (7 repeats) was about $\pm 3 \%$.

SCR experiments were carried out with mixtures of $\left(0.1 \% \mathrm{NO}+8 \% \mathrm{O}_{2}+\mathrm{x}_{0} \mathrm{C}_{1}-\mathrm{C}_{3}\right.$ alcohol $+\mathrm{y} \% \mathrm{H}_{2} \mathrm{O}$ ) in $\mathrm{He}$ carrier gas at temperatures from 300 to $600{ }^{\circ} \mathrm{C}$ and space velocities $\mathrm{SV}$ $=60,000 \mathrm{~h}^{-1}$. The concentrations of alcohols were varied from zero to $2 \%$ and that of water from 3 to $10 \%$. To get comparative information about the catalytic performance of SMMCs for the reduction of $\mathrm{NO}$ by various reductants, experiments were also done by using $\mathrm{H}_{2}, \mathrm{CO}$, and hydrocarbons instead of alcohols. The reaction steps were probed by using bimolecular feeds of $\left(\mathrm{NO}+\mathrm{O}_{2}\right),(\mathrm{NO}+$ alcohol $)$ and $\left(\mathrm{O}_{2}+\right.$

\section{RESULTS}

\section{Reactions with $\mathrm{H}_{2}$ and $\mathrm{CO}$}

Table 1 summarizes results for the total NO conversion in the presence of various reductants. As seen in the first line of this table, the In-SMMC showed a very slight catalytic activity for the direct decomposition of NO. Possibly due to the lack of $\mathrm{H}_{2}$ or $\mathrm{CO}$ adsorption on In [39], we could not measure $\mathrm{NO}$ in the reactions of $\left(0.1 \% \mathrm{NO}+0.5 \% \mathrm{H}_{2}\right)$ and $(0.1 \% \mathrm{NO}+1 \%$ 
CO) either. Since oxygen readily adsorbs on this metal $[30,39,40]$ and even the noble metal based three way catalysts (TWC) need slightly oxidizing conditions for optimum activity in the reduction of $\mathrm{NO}$ by $\mathrm{CO}$ and $\mathrm{H}_{2}$ [41], experiments with a mixture of $\left(0.1 \% \mathrm{NO}+0.35 \% \mathrm{H}_{2}+1 \%\right.$ $\mathrm{CO}+0.75 \% \mathrm{O}_{2}$ ) were also carried out. As Table 1 indicates, a slight NO conversion occurs with these reactants at $500{ }^{\circ} \mathrm{C}$. However, further change was not observed when the concentration of $\mathrm{O}_{2}$ was increased up to $2 \%$.

Table 2 shows the conversions of different reductants in various reactions. In accordance with the deficiency of $\mathrm{CO}$ adsorption on In, measurable $\mathrm{CO}$ conversion was not observed in the reactions of $\mathrm{CO}, \mathrm{O}_{2}$, and $\mathrm{NO}$ over the $28 \% \mathrm{In} / \mathrm{PG}-75$ catalyst. Some examples are shown in the first two lines in Table 2. However, it is perhaps noteworthy that a substantial CO conversion to $\mathrm{CO}_{2}$ was measured with $\left(0.8 \% \mathrm{CO}+1 \% \mathrm{H}_{2} \mathrm{O}\right)$ reactants above $500{ }^{\circ} \mathrm{C}$ although the space velocity was very high, $120,000 \mathrm{~h}^{-1}$. We also observed that more water enhances the conversion of CO, but this reaction has not been systematically studied over the In-SMMC. It is well known that In can react with $\mathrm{H}_{2} \mathrm{O}$ above $200{ }^{\circ} \mathrm{C}$ [42]. The extent of indium oxidation at various temperatures in the presence of $\mathrm{H}_{2} \mathrm{O}$ is currently studied on In-SMMC [30].

\section{Reaction of $\mathrm{NO}$ and $\mathrm{O}_{2}$}

While dearth of appreciable catalytic activity in reactions of $\left(\mathrm{NO}+\mathrm{H}_{2}+\mathrm{CO}+\mathrm{O}_{2}\right)$ is typical for SCR catalysts $[1,2,38,43,44]$, they are usually highly active for the oxidation of NO to $\mathrm{NO}_{2}$ which is believed to be a major reaction step in the SCR process over most catalysts [2, 19, 20, 45-52]. Data in Table 1 demonstrate that the In-SMMC is only slightly active for the oxidation of $\mathrm{NO}$ even in the presence of a large excess of $\mathrm{O}_{2}$. 


\section{Reactions with $\mathrm{C}_{3} \mathrm{H}_{8}$}

The SCR of NO by $\mathrm{C}_{3} \mathrm{H}_{8}$ can only result in selective $\mathrm{N}_{2}$ formation over many ZSM5 catalysts when the molar ratio of $\mathrm{C}_{3} \mathrm{H}_{8} / \mathrm{NO} \geq 1$ in the feed $[51,52]$. Therefore, different $\mathrm{C}_{3} \mathrm{H}_{8} / \mathrm{NO}$ ratios were used in experiments over $28 \% \mathrm{In} / \mathrm{PG}-75$. As a few example in Table 1 demonstrate, negligible $\mathrm{NO}$ conversion was measured with $\mathrm{C}_{3} \mathrm{H}_{8}$ reductant in the absence of oxygen and not much higher in the presence of oxygen. Regardless of the ratio of reactants, NO was selectively converted to $\mathrm{NO}_{2}$ in the reaction of $\left(\mathrm{NO}+\mathrm{C}_{3} \mathrm{H}_{8}+\mathrm{O}_{2}\right)$. This result is quite different from those observed over supported $\operatorname{In}_{2} \mathrm{O}_{3}$ catalysts. For example, Kintaichi et al. [20] reported 25\%, Haneda et al. [21] 18\%, and Maunula et al. [19] 89\% conversions for the SCR of $\mathrm{NO}$ to $\mathrm{N}_{2}$ by $\mathrm{C}_{3} \mathrm{H}_{8}$ at $500{ }^{\circ} \mathrm{C}$ using $6 \% \mathrm{In}_{2} \mathrm{O}_{3} / \mathrm{TiO}_{2}-\mathrm{ZrO}_{2},\left(6 \% \mathrm{In}_{2} \mathrm{O}_{3}+0.005 \% \mathrm{Pd}\right) / \mathrm{TiO}_{2}-\mathrm{ZrO}_{2}$, and $12 \% \mathrm{In}_{2} \mathrm{O}_{3} /$ sol-gel $\mathrm{Al}_{2} \mathrm{O}_{3}$ catalysts, respectively. Albeit these authors used much lower space velocities $\left(\mathrm{SV}=20,000 \mathrm{~h}^{-1}\right)$ than we, it is likely that the substantial difference between both the activities and selectivities of their indium oxide based and our metallic indium based catalysts can mainly be attributed to the different supports and/or oxidation states of indium in the equilibrated catalyst samples.

Interestingly, the reactivity of $\mathrm{C}_{3} \mathrm{H}_{8}$ over In-SMMC appears to be similar to those observed in the aforementioned reports. Examples in Table 2 indicate that negligible direct reaction occurs between $\mathrm{C}_{3} \mathrm{H}_{8}$ and $\mathrm{NO}$, but the combustion of $\mathrm{C}_{3} \mathrm{H}_{8}$ by $\mathrm{O}_{2}$ is substantial near 500 ${ }^{\circ} \mathrm{C}$. This latter reaction is not affected noticeably when NO is also present. Using reactant mixtures composed of roughly $\left(0.1 \% \mathrm{NO}+0.1 \% \mathrm{C}_{3} \mathrm{H}_{8}+10 \% \mathrm{O}_{2}\right)$, Kintaichi et al. [20], Haneda 
et al. [21], and Maunula et al. [19] reported 50\%, 75\%, and 50\% conversions for $\mathrm{C}_{3} \mathrm{H}_{8}$ at $\mathrm{SV}=$ $20,000 \mathrm{~h}^{-1}$ and $500{ }^{\circ} \mathrm{C}$ over their above mentioned three catalysts, respectively.

\section{Reactions with alcohols}

In spite of the low reactivity of $\mathrm{NO}$ with $\mathrm{C}_{3} \mathrm{H}_{8}$, substantial $\mathrm{NO}$ conversions were observed when methanol (Met-OH), ethanol (Et-OH), or 2-propanol (Prop-OH) were used as reactants over In-SMMC. An example with $(\mathrm{Et}-\mathrm{OH}+\mathrm{NO})$ in Table 1 indicates that the onset of this reaction does not require oxygen. Similar observations were made over $\mathrm{Cu}-\mathrm{ZSM} 5$ and $\mathrm{CuO} / \mathrm{g}$ $\mathrm{Al}_{2} \mathrm{O}_{3}$ catalysts by Montreuil and Shelef [38] who pointed out this distinct feature of partially oxygenated reductants versus hydrocarbons which only react with NO in the presence of excess oxygen (Table 1 shows that the conversion of NO increased over the In-SMMC as well, when $\mathrm{O}_{2}$ was added to the mixture of $\left.\left[\mathrm{NO}+\mathrm{C}_{3} \mathrm{H}_{8}\right]\right)$. In further accordance with these authors' observations [38], oxygen slightly suppressed the conversion of $\mathrm{NO}$ in the reaction of (NO + EtOH) (Table 1, $400{ }^{\circ} \mathrm{C}$ ). However, $\mathrm{NO}$ reacted more vigorously when $\mathrm{H}_{2} \mathrm{O}$ was also added to these reactants below about $500{ }^{\circ} \mathrm{C}$.

Separate experiments were done for studying the effects of $\mathrm{O}_{2}, \mathrm{H}_{2} \mathrm{O}$, and $\mathrm{NO}$ on the reactivity of Met-OH and Et-OH over various SMMC samples [27, 28]. As seen in Table 2, these alcohols readily react over the In-SMMC even at very high space velocities in the absence of other reactants. Independent studies indicate that the major products involve aldehydes [28]. Table 2 also shows that $\mathrm{H}_{2} \mathrm{O}$ does not affect substantially the dehydrogenation of Met-OH, but even a small amount of $\mathrm{O}_{2}$ initiates its total burning. While the effect of $\mathrm{NO}$ on the reactivity of Met-OH was not investigated, Table 2 shows that NO has an even more pronounced effect on 
the conversion of Et-OH (products were not analyzed) than $\mathrm{O}_{2}$ and the two oxidants together generate an additional increase in the Et-OH conversion. When the space velocity was drastically decreased from 120,000 to $12,000 \mathrm{~h}^{-1}$ (which still approximates the conditions in stationary exhausts), total alcohol conversion could be attained near $400{ }^{\circ} \mathrm{C}$ even at elevated Et-OH concentrations in the feed.

The complex effects of $\mathrm{H}_{2} \mathrm{O}$ and $\mathrm{O}_{2}$ on the reactivity of Et-OH and the distribution of products at various temperatures are detailed elsewhere [28]. However, it is important to note here that the reaction of $\left(1 \% \mathrm{Et}-\mathrm{OH}+3.3 \% \mathrm{H}_{2} \mathrm{O}+\mathrm{x} \% \mathrm{O}_{2}\right)$ typically results in selective acetaldehyde production near $500{ }^{\circ} \mathrm{C}$. Thus, similar to the very recently reported $\mathrm{Ag} / \mathrm{Al}_{2} \mathrm{O}_{3}$ [36], acetaldehyde might be an intermediate reactant in the SCR of NO by Et-OH over In-SMMC. Comparative data in Table 1 and Table 2 also indicate that Et-OH and NO can mutually affect each other's reactivities which is typical for radical processes [50, 57].

Selectivity for $\mathrm{NO}_{2}$ and $\mathrm{N}_{2}\left(\mathrm{~N}_{2} \mathrm{O}\right)$

While Table 1 illustrates that Et-OH and $\mathrm{O}_{2}$ initiate substantial $\mathrm{NO}$ conversion, the separate analysis of $\mathrm{NO}$ and $\mathrm{NO}_{2}$ in the effluents and the calculated nitrogen balance indicate that only a part of $\mathrm{NO}$ could be transformed to $\mathrm{N}_{2}\left(\mathrm{~N}_{2} \mathrm{O}\right)$ at certain reaction conditions. Note that the nitrogen balance merely permits the determination of total unfixed nitrogen (molecules with stable $\mathrm{N} \equiv \mathrm{N}$ bonds which cannot revert to fixed $\mathrm{NO}_{\mathrm{x}}$ in the exhaust systems $\left.[58,59]\right)$ which includes both $\mathrm{N}_{2}$ and $\mathrm{N}_{2} \mathrm{O}$ and we have not determined their relative amounts in the present studies.

Fig. 1 shows, for example, that the direct reaction of $(\mathrm{NO}+\mathrm{Et}-\mathrm{OH})$ in absence of $\mathrm{O}_{2}$ mainly results in $\mathrm{NO}_{2}$ (difference of [total $\mathrm{NO}-\mathrm{NO}$ to $\mathrm{N}_{2}$ ] conversions). By adding $\mathrm{O}_{2}$ to these 
reactants, the selectivity for $\mathrm{N}_{2}$ increases. The total conversion of $\mathrm{NO}$ goes through a minimum with increasing oxygen concentrations which is a quite unusual phenomenon. It is possible that these reactivity and selectivity changes for NO are related to selectivity changes in converting Et$\mathrm{OH}$ to aldehyde or $\mathrm{CO}_{\mathrm{x}}$ which also depend on the concentration of oxygen over the In-SMMC [28].

Table 3 compares the total conversions of $\mathrm{NO}$ and the selective conversions of $\mathrm{NO}$ to $\mathrm{N}_{2}$ $\left(\mathrm{N}_{2} \mathrm{O}\right)$ by various alcohols at oxidizing conditions in the presence and absence of $\mathrm{H}_{2} \mathrm{O}$ at $500{ }^{\circ} \mathrm{C}$. The extreme $\mathrm{NO}_{2}$ production (difference of [column 1 - column 2]) with Met-OH and Prop-OH in the absence of $\mathrm{H}_{2} \mathrm{O}$ can only be attributed to reactions in the post-reactor system. At this temperature, the thermodynamic equilibrium for the reaction $\mathrm{NO}+1 / 2 \mathrm{O}_{2} \Leftrightarrow \mathrm{NO}_{2}$ would only permit about $18 \%$ conversion of $\mathrm{NO}$ to $\mathrm{NO}_{2}$ [49], which is roughly the measured value in case of Et-OH. Substantial $\mathrm{NO}_{2}$ formation was not observed in the absence of alcohols when the reactants are $\left(\mathrm{NO}+\mathrm{O}_{2}\right)($ Table 1$)$ and the conversion of $\mathrm{NO}$ is negligible at $<350{ }^{\circ} \mathrm{C}$ even in the presence of catalyst when $(\mathrm{NO}+$ alcohol) are the only reactants (Table 1). Thus, probably the reaction of (alcohol $+\mathrm{O}_{2}$ ) can result in reactive products, e.g., long lived peroxy radicals, which, released from the reactor, can still generate substantial $\mathrm{NO}_{2}$. An example is the reaction of $\mathrm{RO}_{2}+$ $\left.\mathrm{NO}==>\mathrm{RO}+\mathrm{NO}_{2}\right)[50,57]$. The degradation of aldehydes to peroxy radicals and their low temperature interactions with NO are well known atmospheric processes [60]. Our early results [28] confirm the possibility of aldehyde formation over In-SMMC. Moreover, we observed periodic oscillations in the $\mathrm{NO}$ and $\mathrm{NO}_{2}$ concentrations of the reactor effluents which is a direct 
evidence for the presence and release of radicals in our reaction system. This issue will be addressed elsewhere [29].

As the examples of Et-OH and Prop-OH in Table 3 indicate, $\mathrm{H}_{2} \mathrm{O}$ quenches the formation of $\mathrm{NO}_{2}$ (probably a post-reactor process, thus Met-OH was not tested in the presence of $\mathrm{H}_{2} \mathrm{O}$ ) but leaves the $\mathrm{N}_{2}$ formation largely intact (Et-OH) or promotes it (Prop-OH) near $500{ }^{\circ} \mathrm{C}$.

Using the most selective reductant, Et-OH, we investigated the effect of reaction temperature on the catalyst activity and selectivity for the reaction of $(0.1 \% \mathrm{NO}+1 \% \mathrm{Et}-\mathrm{OH}+$ $8 \% \mathrm{O}_{2}$ ) in the presence and absence of $\mathrm{H}_{2} \mathrm{O}$. Results are summarized in Fig. 2. When the feed does not contain $\mathrm{H}_{2} \mathrm{O}$, $\mathrm{NO}$ is mainly converted to $\mathrm{NO}_{2}$ at temperatures $\leq 450{ }^{\circ} \mathrm{C}$, but largely selective $\mathrm{N}_{2}$ production occurs at higher temperatures. The increased $\mathrm{N}_{2}$ formation might be associated with the oxidation of In [30] or the accelerated reaction of $\left(\mathrm{O}_{2}+\mathrm{Et}-\mathrm{OH}\right)$ [28] or both.

The substantial unreacted $\mathrm{NO}_{2}$ (difference of [total $\mathrm{NO}-\mathrm{NO}$ to $\mathrm{N}_{2}$ ) either indicates sluggish $\mathrm{NO}_{2}+$ Et-OH reactivity over this catalyst or formation of $\mathrm{NO}_{2}$ in the post-reactor system as proposed above.

In presence of $\mathrm{H}_{2} \mathrm{O}$, the $\mathrm{N}_{2}$ production clearly increases at temperatures $<500{ }^{\circ} \mathrm{C}$ (Fig. 2). Since the maximum concentration of $\mathrm{NO}_{2}$ roughly follows the equilibrium maxima above $400{ }^{\circ} \mathrm{C}$ [49], it is likely that the oxidation of $\mathrm{NO}$ to $\mathrm{NO}_{2}$ proceeds in the catalytic reactor. We attempted to add $\mathrm{C}_{3} \mathrm{H}_{8}$ to the feed to convert this extra $\mathrm{NO}_{2}$ but no significant change in the $\mathrm{NO}_{2}$ or $\mathrm{N}_{2}$ concentration was observed. 


\section{DISCUSSION}

The SCR of NO by hydrocarbons in presence of oxygen can be considered as a special combustion of hydrocarbons which also involves $\mathrm{NO}_{\mathrm{x}}[47,51,52,55]$. Since $\mathrm{NO}_{2}$ is a very reactive moiety compared to $\mathrm{NO}$ and the oxidation of $\mathrm{NO}$ to $\mathrm{NO}_{2}$ is typically faster than the direct interaction of $\mathrm{NO}$ and hydrocarbons over most SCR catalysts, formation of $\mathrm{NO}_{2}$ is widely regarded as initial reaction step in SCR processes [1, 2, 49-52]. Such mechanisms have commonly been proposed for the SCR of NO over In-based catalysts as well [17-21].

The direct reaction of $\mathrm{NO}$ and Et-OH (Table 1) demonstrates that $\mathrm{NO}_{2}$ is not needed to initiate the reaction of alcohols over In-SMMC. In fact, data in Table 1 and Table 2 indicate that the decomposition and direct oxidation of alcohols by $\mathrm{O}_{2}$ are faster reactions over this catalyst than the oxidation of $\mathrm{NO}$ by $\mathrm{O}_{2}$. Moreover, data in Table 3 and Fig. 2 show that $\mathrm{NO}_{2}$ formation only becomes substantial in presence of alcohols. Thus, it is likely that either the oxidation of alcohols or the direct reaction of alcohols with NO can initiate the SCR process and formation of $\mathrm{NO}_{2}$ is mainly due to secondary reactions over In-SMMC. Similar reaction pathway was suggested for silver [36] and transition metal based catalysts [25, 52, 56] as well as for H-ZSM5 above $500{ }^{\circ} \mathrm{C}$ [51]. While $\mathrm{NO}_{2}$ might participate in the SCR process, it appears that its formation is either much faster than its further reaction with intermediates to form $\mathrm{N}_{2}$ or the measured $\mathrm{NO}_{2}$ largely forms in the post-reactor system. In situ $\mathrm{NO}_{2}$ formation was not reported in the SCR of NO by alcohols over other In-based catalysts but $\mathrm{NO}_{2}$ was found to be slightly more reactive than NO [19-21]. Thus the SCR of NO by alcohols probably follows a different reaction path over In-SMMC than over other catalysts. As pointed out at several experimental 
findings, radical reactions are probably integral parts of the overall SCR process over the InSMMC.

While the reaction pathway has yet to be explored, the new In-SMMC is certainly one of the most active catalysts for converting $\mathrm{NO}$ to $\mathrm{N}_{2}$ by alcohols in presence of excess $\mathrm{O}_{2}$ and $\mathrm{H}_{2} \mathrm{O}$. This is demonstrated in Table 4 which shows relevant data for the SCR of $\mathrm{NO}$ by Et-OH in presence of $\mathrm{H}_{2} \mathrm{O}$ over all catalysts we have found in the literature. Although the scattering reactant concentrations and space velocities permit only a rough comparison, it is clear that only a very recently published [36] $\mathrm{Ag} / \mathrm{Al}_{2} \mathrm{O}_{3}$ catalyst shows similar or better efficiency for converting $\mathrm{NO}$ to $\mathrm{N}_{2}\left(\mathrm{~N}_{2} \mathrm{O}\right)$ at wet conditions as the In-SMMC. Moreover, the InSMMC is the first $\mathrm{SiO}_{2}$ supported highly active SCR catalyst.

Besides its high catalytic activity for the reactions of $\left(\mathrm{NO}+\mathrm{Et}-\mathrm{OH}+\mathrm{O}_{2}+\mathrm{H}_{2} \mathrm{O}\right)$, InSMMC showed several distinct catalytic properties compared to those of other In-based SCR catalysts. i) In contrast to other catalysts, In-SMMC is largely inactive for the reduction of NO by $\mathrm{C}_{3} \mathrm{H}_{8}$ but active for the reduction of $\mathrm{NO}$ by alcohols. For example, Maunula et al. [19] found $85 \%$ and $30 \%$ conversions ( $\mathrm{NO}$ to $\mathrm{N}_{2}$ ) over an $\mathrm{In}_{2} \mathrm{O}_{3} / \mathrm{Al}_{2} \mathrm{O}_{3}$ catalyst by using $\mathrm{C}_{3} \mathrm{H}_{8}$ and alcohol reductants, respectively. ii) $\mathrm{H}_{2} \mathrm{O}$ has typically either negligible or slightly retarding effect on the catalytic activities of traditional In-based catalysts when alcohols are the reductants [19, 21].

Data in Table 3 and Fig 2 indicate that $\mathrm{H}_{2} \mathrm{O}$ has activity and selectivity boosting effect on InSMMC at various reaction conditions. To our knowledge, similar effect has only been observed over a mixed $\mathrm{Mn}_{2} \mathrm{O}_{3} / \mathrm{Sn}$-ZSM5 (with $\mathrm{C}_{3} \mathrm{H}_{6}$ reductant) [54] and $\mathrm{Ag} / \mathrm{Al}_{2} \mathrm{O}_{3}$ (Et-OH reductant) [36] catalyst. iii) The efficiency of alcohols to convert $\mathrm{NO}$ to $\mathrm{N}_{2}\left(\mathrm{~N}_{2} \mathrm{O}\right)$ typically follows the order 
Met-OH $<$ Et-OH $<$ Prop-OH [19-21], while Et-OH was found to be more efficient over InSMMC than the other two alcohols (Table 3). iv) Oxidative promoters, such as $\mathrm{Mn}_{3} \mathrm{O}_{4}$, are needed to boost $\mathrm{NO}_{2}$ formation, for instance, over the $\mathrm{Al}_{2} \mathrm{O}_{3}$ supported $\mathrm{In}_{2} \mathrm{O}_{3}$ catalyst [19], while substantial unreacted $\mathrm{NO}_{2}$ can form in presence of alcohols over the $28 \% \mathrm{In} / \mathrm{PG}-75$ catalyst [Table 3, Fig. 2]. The proposed major function of surface In sites over In, H-ZSM5 [8], $\mathrm{In}_{2} \mathrm{O}_{3} / \mathrm{TiO}_{2}-\mathrm{ZrO}_{2}[21]$, or $\mathrm{In}_{2} \mathrm{O}_{3} / \mathrm{Al}_{2} \mathrm{O}_{3}$ [19] catalysts is the promotion of reactions of $\left(\mathrm{NO}_{2}+\right.$ oxygenated intermediates). Data in Fig. 2 suggest that this reaction might be slow over the InSMMC and the disappearance of excess $\mathrm{NO}_{2}$ at temperatures $\geq 500{ }^{\circ} \mathrm{C}$ can mainly be attributed to changes in the $\mathrm{NO} / \mathrm{NO}_{2}$ equilibrium [49] (but the conversion of $\mathrm{NO}$ to $\mathrm{N}_{2}$ is faster over the InSMMC than over other In-based catalysts as Table 4 shows).

\section{ACKNOWLEDGMENT}

The authors thank Ms. Manuela Serban for surface area and porosity measurements. DOE research grants \#DE-FG02-96ER12184 and \#DE-FG26-97FT97268 are also thankfully acknowledged. 


\section{REFERENCES}

[1] J. N. Armor, Appl. Catal. B: Environmental 1 (1992) 221.

[2] M. Shelef, Chem. Rev. 95 (1995) 209.

[3] M. Iwamoto, H. Yahiro, Y. Yu-U, S. Shundo, N. Mizuno, Shokubai 32 (1990) 430.

[4] W. Held, A. Koenig, T. Richter, L. Puppe, SAE Paper 900496 (1990).

[5] H. Hamada, Y. Kintaichi, M. Sasaki, T. Ito, M. Tabata, Appl. Catal. 64 (1990) L1.

[6] Y. Li, P. J. Battavio, J. N. Armor, J. Catal. 142 (1993) 561.

[7] R. A. Grinsted, H.-W. Jen, C. N. Montreuil, M. J. Rokosz, M. Shelef, Zeolites 13 (1993) 602.

[8] M. Ogura, E. Kikuchi, Stud. Surf. Sci. Catal. 101 (1996) 671.

[9] X. Feng, W. K. Hall, J. Catal. 166 (1997) 368.

[10] I. Halasz, J. Horvath, T. Mandy, L. Schmidt, E. Tasnadi, Stud. Surf. Sci. Catal. 24 (1985) 393.

[11] M. Iwamoto, J. Wang, K. M. Sperati, T. Sajiki, M. Misono, Chem. Lett. 1281 (1997).

[12] A. Martinez, S. A. Gomez, G. A. Fuentes, Catalyst Deactivation (Elsevier; ed. by C. H. Bartholomew \& G. A. Fuentes) pp. 225 (1997).

[13] H-Y. Chen, W. M. H. Sachtler, Catal. Lett. 50 (1998) 125.

[14] E. Kikuchi, K. Yogo, Catal. Today, 22 (1994) 73.

[15] X. Zhou, T. Zhang, Z. Xu, L. Lin, Catal. Lett. 40 (1996) 35.

[16] T. Tabata, M. Kokitsu, O. Okada, Appl. Catal. B: Environmental, 6 (1995) 225.

[17] E. Kikuchi, M. Ogura, I. Terasaki, Y. Goto, J. Catal. 161 (1996) 465.

[18] T. Miyadera, K. Yoshida, Chem. Lett. 1483 (1993). 
[19] T. Maunula, Y. Kintaichi, M. Inaba, M. Haneda, K. Sato, H. Hamada, Appl. Catal. B: Environmental 15 (1998) 291.

[20] Y. Kintaichi, M. Haneda, M. Inaba, H. Hamada, Catal. Lett. 48 (1997) 121.

[21] M. Haneda, Y. Kintaichi, M. Inaba, H. Hamada, Bull. Chem. Soc. Jpn. 70 (1997) 2171.

[22] M. Tabata, H. Hamada, F. Suganuma, T. Yoshinari, H. Tcsuchida, Y. Kintaichi, M. Sasaki, T. Ito, Catal. Lett. 25 (1994) 55.

[23] S. Subramanian, R. J. Kudla, W. Chun, M. S. Chattha, Ind. Eng. Chem. Res. 32 (1993) 1805.

[24] H. Tsuchida, M. Tabata, K. Miyamoto, T. Yoshinari, H. Yamazaki, SAE Techn. Papers 940242 (1994).

[25] H. Hamada, Y. Kintaichi, T. Yoshinari, M. Tabata, M. Sasaki, T. Ito, Catal. Today 17 (1993) 111.

[26] R. Datta, I. Halasz, M. Serban, A. Singh, US Patent, pending.

[27] I. Halasz, A. Singh, M. Serban, R. Datta, Science, in preparation.

[28] I. Halasz, R. Datta, Appl. Catal. A: General, in preparation.

[29] I. Halasz, R. Datta, J. Phys. Chem., in preparation.

[30] C. Phillips, I. Halasz, M. Serban, R. Datta, Catal. Lett., in preparation.

[31] K. Taylor, Catal. Rev. Sci. Eng. 35 (1992) 457.

[32] C. J. Pereira, K. W. Plumlee, Catalysis Today 13 (1992) 23.

[33] P. Harriott, J. M. Markussen, Ind. Eng. Chem. Res. 31 (1992) 373.

[34] V. Visciglio, G. Blanchard, R. Surantyn, Catal. Lett. 40 (1996) 39.

[35] T. Miyadera, Appl. Catal. B: Environmental 2 (1993) 199. 
[36] S. Sumiya, M. Saito, H. He, Q-C. Feng, N. Takezawa, K. Yoshida, Catal. Lett. 50 (1998) 87.

[37] H. Hamada, Y. Kintaichi, M. Sasaki, T. Ito, Appl. Catal. A: General 88 (1992) L1.

[38] C. N. Montreuil, M. Shelef, Appl. Catal. B: Environmental 1 (1992) L1.

[39] B. M. W. Trapnell, Proc. Roy. Soc. A218 (1953) 566.

[40] M. Serban, I. Halasz, R. Datta, unpublished results.

[41] I. Halasz, A. Brenner, M. Shelef, Catal. Lett. 22 (1993) 147.

[42] Comprehensive Inorganic Chemistry (First Edition; Pergamon Press) Vol. 3, pp. 1065 (1973).

[43] M. Iwamoto, N. Mizuno, J. Automotive Eng. 207 (1993) 23.

[44] J. S. Feeley, M. Deeba, R. J. Farrauto, G. Beri, A. Haynes, Appl. Catal. B: Environmental $6(1995) 79$.

[45] H. Hamada, Y. Kintaichi, M. Sasaki, T. Ito, Appl. Catal. 70 (1991) L15.

[46] M. Shelef, C. M. Montreuil, H. W. Jen, Catal. Lett. 26 (1994) 277.

[47] F. Witzel, G. A. Sill, W. K. Hall, J. Catal. 149 (1994) 229.

[48] T. Beutel, B. J. Adelman, G. D. Lei, W. M. Sachtler, Catal. Lett. 32 (1995) 83.

[49] I. Halasz, A. Brenner, K. Y. S. Ng, Catal. Lett. 34 (1995) 151.

[50] I. Halasz, A. Brenner, M. Shelef, K. Y. S. Ng, J. Phys. Chem. 99 (1995) 17186.

[51] I. Halasz, A. Brenner, K. Y. S. Ng, Y. Hou, J. Catal. 161 (1996) 359.

[52] I. Halasz, A. Brenner, Catal. Lett. 51 (1998) in press.

[53] H. Hamada, Y. Kintaichi, M. Sasaki, T. Ito, M. Tabata, Appl. Catal. 75 (1991) L1.

[54] Y. Hirao, C. Yokoyama, M. Misono, Chem. Commun. 597 (1996).

[55] D. B. Lukyanov, E. A. Lombardo, G. Sill, J. L. d'Itri, W. K. Hall, J. Catal. 163 (1996) 447. 
[56] M. Sasaki, H. Hamada, Y. Kintaichi, T. Ito, Catal. Lett. 15 (1992) 297.

[57] J. B. Bromly, F. J. Barnes, R. Mandyczewsky, T. J. Edwards, B. S. Haynes, in Proceedings of the 24th International Symposium on Combustion (Sydney, Australia; organized by the Combustion Inst., Pittsburgh, Pennsylvania) pp. 899 (1992).

[58] M. Shelef, J. T. Kummer, Chem. Eng. Prog. Symp. Ser. 67 (1971) 74.

[59] M. Shelef, H. S. Gandhi, Ind. Eng. Chem. Prod. Res. Develop. 11 (1972) 2.

[60] J. Sehested, L. K. Christensen, T. Mogelberg, O. J. Nielsen, T. J. Wallington, A. Guschin, J. J. Orlando, G. S. Tyndall, J. Phys. Chem. A102 (1998) 1779. 


\section{LEGENDS TO TABLES AND FIGURES}

Table 1. Effect of $\mathrm{O}_{2}, \mathrm{H}_{2} \mathrm{O}$, and $\mathrm{NO}$ on the conversion of various reductants over $28 \%$ In/PG75 catalyst $(\mathrm{nm}=$ not measured) .

Table 2. Conversion of $\mathrm{NO}$ in the presence and absence of $\mathrm{O}_{2}$ and various reactants; catalyst: $28 \% \mathrm{In} / \mathrm{PG}-75$; total pressure $=0.1 \mathrm{MPa} ; \mathrm{SV}=60,000 \mathrm{~h}^{-1}$.

Table 3. Comparison the efficiency of different alcohols in the SCR of NO in the presence and absence of $\mathrm{H}_{2} \mathrm{O}$; catalyst: $28 \% \mathrm{In} / \mathrm{PG}-75$ catalyst; reactants: $[0.1 \% \mathrm{NO}+1 \%$ alcohol + $8 \% \mathrm{O}_{2}+\mathrm{x} \% \mathrm{H}_{2} \mathrm{O}$ ] in $\mathrm{He}$ carrier gas; reaction temperature: $500{ }^{\circ} \mathrm{C}$; total pressure $=0.1$ $\mathrm{MPa} ; \mathrm{SV}=60,000 \mathrm{~h}^{-1}$.

Table 4. Comparison the activities of catalysts for the SCR of NO by Et-OH in presence of excess $\mathrm{O}_{2}$ and $\mathrm{H}_{2} \mathrm{O}$; reactants: [(0.05-0.1)\% $\mathrm{NO}+(0.2-1 \%) \mathrm{Et}-\mathrm{OH}+(8-10) \%$ $\left.\mathrm{O}_{2}+(3-10) \% \mathrm{H}_{2} \mathrm{O}\right]$ in $\mathrm{He}$ carrier gas.

Fig. 1 Effect of the concentration of $\mathrm{O}_{2}$ on the total conversion of $\mathrm{NO}$ and the conversion of $\mathrm{NO}$ to $\mathrm{N}_{2}\left(\mathrm{~N}_{2} \mathrm{O}\right)$; catalyst: $28 \% \mathrm{In} / \mathrm{PG}-75$; reactants: $\left(0.1 \% \mathrm{NO}+1 \% \mathrm{Et}-\mathrm{OH}+\mathrm{x} \% \mathrm{O}_{2}\right)$; reaction temperature: $400{ }^{\circ} \mathrm{C}$; total pressure $=0.1 \mathrm{MPa} ; \mathrm{SV}=60,000 \mathrm{~h}^{-1}$.

Fig. 2 Effect of the reaction temperature on the total conversion of $\mathrm{NO}$ and conversion of $\mathrm{NO}$ to $\mathrm{N}_{2}\left(\mathrm{~N}_{2} \mathrm{O}\right)$ in the reduction of $0.1 \% \mathrm{NO}$ by $1 \%$ Et-OH at oxidizing conditions in the presence (dashed lines) and absence (continuous lines) of $\mathrm{H}_{2} \mathrm{O}$ over $28 \% \mathrm{In} / \mathrm{PG}-75$ catalyst; total pressure $0.1 \mathrm{MPa} ; \mathrm{SV}=60,000 \mathrm{~h}^{-1}$. 


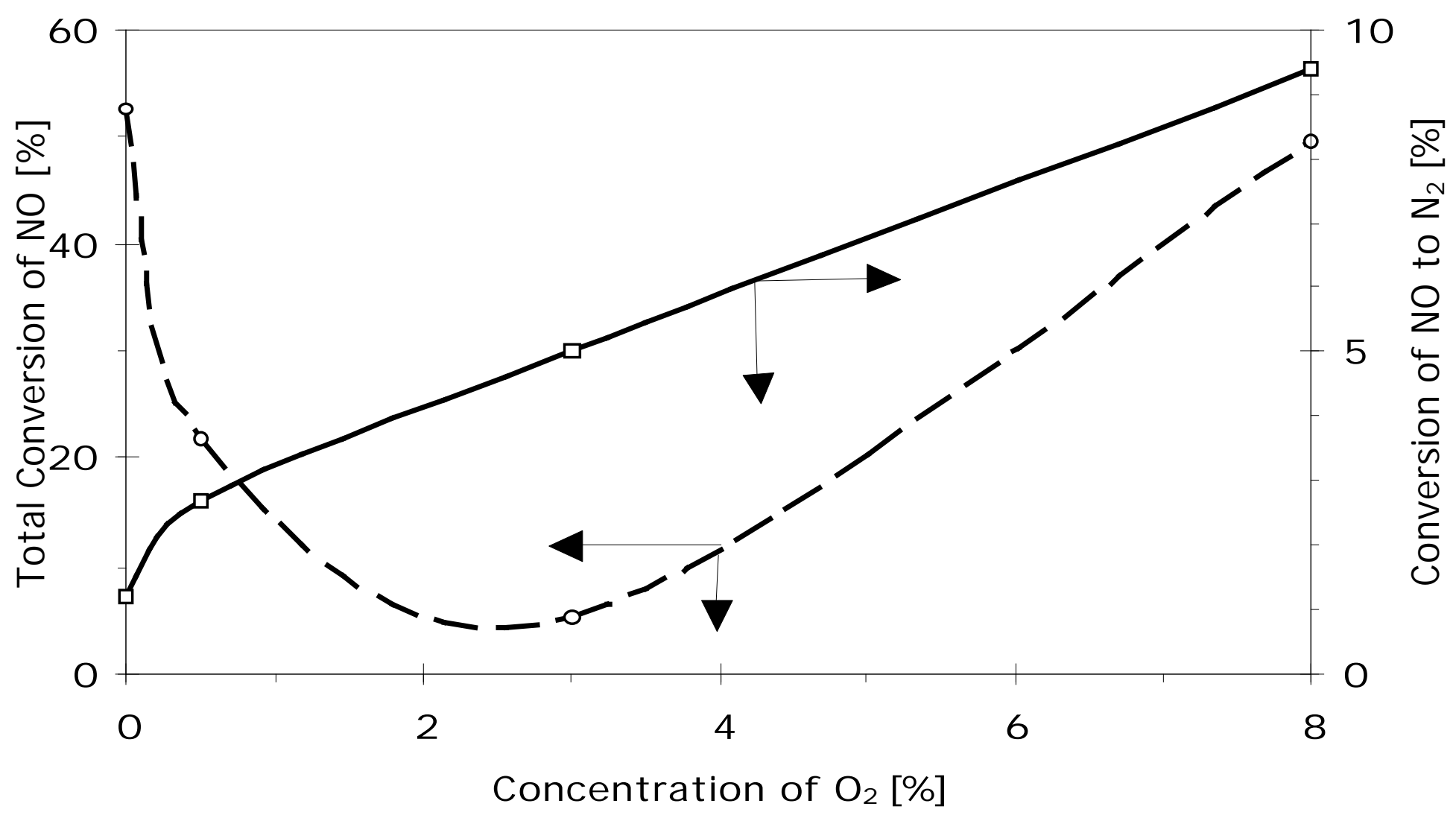




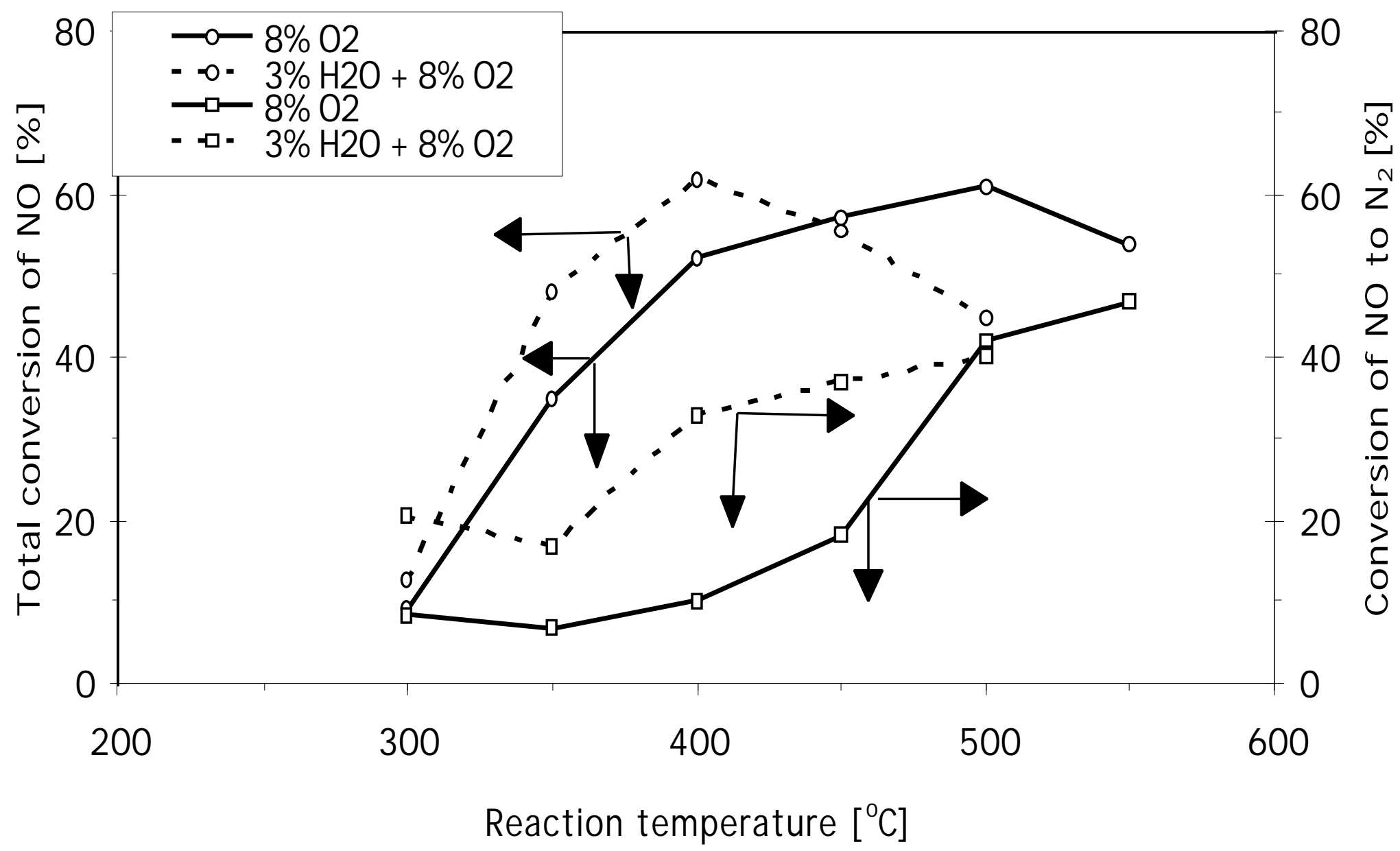




\begin{tabular}{|l|r|r|r|}
\hline \multirow{2}{*}{ Reactants } & \multicolumn{3}{|c|}{ Total Conversion of NO [\%] } \\
\cline { 2 - 4 } & $300{ }^{\circ} \mathrm{C}$ & $400{ }^{\circ} \mathrm{C}$ & $500{ }^{\circ} \mathrm{C}$ \\
\hline $0.1 \% \mathrm{NO}$ & 1.4 & 3.3 & 1.1 \\
$0.1 \% \mathrm{NO}+8 \% \mathrm{O}_{2}$ & 8.1 & 8.6 & 8.6 \\
$0.1 \% \mathrm{NO}+0.35 \% \mathrm{H}_{2}+1 \% \mathrm{CO}+0.75 \% \mathrm{O}_{2}$ & $\mathrm{~nm}$ & $\mathrm{~nm}$ & 2.8 \\
$0.1 \% \mathrm{NO}+0.15 \% \mathrm{C}_{3} \mathrm{H}_{8}$ & 0.0 & 0.9 & 1.0 \\
$0.1 \% \mathrm{NO}+0.15 \% \mathrm{C}_{3} \mathrm{H}_{8}+8 \% \mathrm{O}_{2}$ & $\mathrm{~nm}$ & 6.5 & 6.1 \\
$0.1 \% \mathrm{NO}+1 \% \mathrm{Et}-\mathrm{OH}$ & $\mathrm{nm}$ & 55.6 & $\mathrm{~nm}$ \\
$0.1 \% \mathrm{NO}+1 \% \mathrm{Et}-\mathrm{OH}+8 \% \mathrm{O}_{2}$ & 9.0 & 49.7 & 60.7 \\
$0.1 \% \mathrm{NO}+1 \% \mathrm{Et}-\mathrm{OH}+8 \% \mathrm{O}_{2}+3.3 \% \mathrm{H}_{2} \mathrm{O}$ & 12.8 & 62.0 & 44.6 \\
& & & \\
\hline
\end{tabular}




\begin{tabular}{|c|c|c|c|c|c|c|c|}
\hline \multirow[b]{2}{*}{ Reactants } & \multicolumn{3}{|c|}{ Total Conversion of $\mathrm{CO}, \mathrm{C}$} & \multicolumn{3}{|c|}{${ }_{3} \mathrm{H}_{8}$, Met-OH, or Et-OH [\%] } & \multirow[b]{2}{*}{$S V\left[h^{-1}\right]$} \\
\hline & $300{ }^{\circ} \mathrm{C}$ & $350{ }^{\circ} \mathrm{C}$ & 400 & ${ }^{\circ} \mathrm{C}$ & $500{ }^{\circ} \mathrm{C}$ & $550{ }^{\circ} \mathrm{C}$ & \\
\hline $2 \% \mathrm{CO}+3 \% \mathrm{O}_{2}$ & $\mathrm{nn}$ & $\mathrm{nm}$ & & 0 & & 0 & 60,000 \\
\hline $1 \% \mathrm{CO}+1.3 \% \mathrm{O}_{2}+0.1 \% \mathrm{NO}$ & $\mathrm{nn}$ & $\mathrm{nm}$ & & 0 & & 0 & 60,000 \\
\hline $0.8 \% \mathrm{CO}+1 \% \mathrm{H}_{2} \mathrm{O}$ & ( & 0 & & 0 & & 5 & 120,000 \\
\hline $0.2 \% \mathrm{C}_{3} \mathrm{H}_{8}+2 \% \mathrm{O}_{2}$ & $\mathrm{nn}$ & $\mathrm{nm}$ & & 5 & 6 & & 60,000 \\
\hline $0.2 \% \mathrm{C}_{3} \mathrm{H}_{8}+0.1 \% \mathrm{NO}$ & ( & 0 & & 0 & & 1 & 60,000 \\
\hline $0.2 \% \mathrm{C}_{3} \mathrm{H}_{8}+0.1 \% \mathrm{NO}+2 \% \mathrm{O}_{2}$ & $\mathrm{nn}$ & $\mathrm{nm}$ & & 5 & 6 & 0 & 60,000 \\
\hline $1 \%$ Met-OH & C & 0 & & 1 & & 9 & 120,000 \\
\hline $1 \%$ Met-OH $+0.5 \% \mathrm{O}_{2}$ & $\mathrm{nn}$ & $\mathrm{nm}$ & & 35 & 7 & & 120,000 \\
\hline $1 \%$ Met-OH $+2.3 \% \mathrm{H}_{2} \mathrm{O}$ & $\mathrm{nn}$ & $\mathrm{nm}$ & & 1 & & 8 & 120,000 \\
\hline $1 \% \mathrm{Et}-\mathrm{OH}$ & ( & 1 & & 2 & 2 & & 120,000 \\
\hline $1 \% \mathrm{Et}-\mathrm{OH}+4 \% \mathrm{O}_{2}$ & & 4 & & 12 & 6 & & 120,000 \\
\hline $1 \%$ Et-OH + 0.08\% NO & & 7 & & 20 & $\mathrm{nr}$ & & 120,000 \\
\hline $1 \% \mathrm{Et}-\mathrm{OH}+0.08 \% \mathrm{NO}+4 \% \mathrm{O}_{2}$ & & 12 & & 25 & $\mathrm{nr}$ & & 120,000 \\
\hline $5 \% \mathrm{Et}-\mathrm{OH}+20 \% \mathrm{O}_{2}$ & 2 & 24 & & 42 & $\mathrm{nr}$ & & 12,000 \\
\hline $5 \%$ Et-OH + 0.2\% NO & $i$ & 18 & & 35 & $\mathrm{nr}$ & & 12,000 \\
\hline $5 \% \mathrm{Et}-\mathrm{OH}+0.2 \% \mathrm{NO}+20 \% \mathrm{O}_{2}$ & 2 & 45 & & 100 & $\mathrm{nr}$ & & 12,000 \\
\hline
\end{tabular}




\begin{tabular}{|l|c|c|c|}
\hline & \multirow{2}{*}{ Reductant } & $\mathrm{H}_{2} \mathrm{O}$ [\%] & \multicolumn{2}{|c|}{ Conversion [\%] } \\
\cline { 3 - 4 } & 0.0 & 86.9 & 6.3 \\
\hline Met-OH & 0.0 & 60.7 & 42.1 \\
Et-OH & 3.3 & 44.6 & 40.1 \\
Et-OH & 0.0 & 60.5 & 23.1 \\
2-Prop-OH & 4.2 & 38.1 & 29.5 \\
2-Prop-OH & 4.2 & NO to N \\
\hline
\end{tabular}




\begin{tabular}{|c|c|c|c|c|c|}
\hline \multirow[b]{2}{*}{ Catalyst } & \multicolumn{3}{|c|}{ NO Conversion to $\mathrm{N} \quad{ }_{2}\left(\mathrm{~N}_{2} \mathrm{O}\right)[\%]$} & \multirow[b]{2}{*}{$\mathrm{SV}\left[\mathrm{h}^{-1}\right]$} & \multirow[b]{2}{*}{ Reference } \\
\hline & $300{ }^{\circ} \mathrm{C}$ & $400{ }^{\circ} \mathrm{C}$ & $500{ }^{\circ} \mathrm{C}$ & & \\
\hline In-SMMC & 22 & 38 & 41 & 60,000 & Present Work \\
\hline$\gamma-\mathrm{Al}_{2} \mathrm{O}_{3}$ & 2 & 10 & 19 & 20,000 & {$[25]$} \\
\hline$\gamma-\mathrm{Al}_{2} \mathrm{O}_{3}$ & 22 & $\mathrm{~nm}$ & $\mathrm{~nm}$ & 20,000 & [19] \\
\hline$\gamma-\mathrm{Al}_{2} \mathrm{O}_{3}$ & 45 & 50 & 38 & 10,000 & [24] \\
\hline $\mathrm{In}_{2} \mathrm{O}_{3} / \mathrm{Al}_{2} \mathrm{O}_{3}$ & 30 & $\mathrm{~nm}$ & $\mathrm{~nm}$ & 20,000 & [19] \\
\hline $\mathrm{Ag} / \mathrm{Al}_{2} \mathrm{O}_{3}$ & 42 & 41 & $\mathrm{~nm}$ & 6,400 & [35] \\
\hline $\mathrm{Ag} / \mathrm{Al}_{2} \mathrm{O}_{3}$ & $<38$ & 76 & 68 & 40,000 & [36] \\
\hline $\mathrm{CoO}_{x} / \mathrm{Al}_{2} \mathrm{O}_{3}$ & 48 & 28 & 24 & 2,000 & [37] \\
\hline $\mathrm{Pd}-\mathrm{In}_{2} \mathrm{O}_{3} / \mathrm{TiO}_{2}-\mathrm{ZrO}_{2}$ & 15 & 22 & 10 & 40,000 & [21] \\
\hline H-ZSM5 & 18 & 19 & 10 & 20,000 & [37] \\
\hline Cu-ZSM5 & 28 & 15 & 10 & 20,000 & [37] \\
\hline Cu-ZSM5 & $\mathrm{nm}$ & $\mathrm{nm}$ & 25 & 50,000 & [38] \\
\hline
\end{tabular}

